\title{
Volgonyx gen.n. and Pontonyx gen.n., two new genera of the family Crangonyctidae (Crustacea: Amphipoda) from the southeastern Europe
}

\section{Volgonyx gen.n. и Pontonyx gen.n., два новых рода семейства Crangonyctidae (Crustacea: Amphipoda) из юго-восточной Европы}

\author{
Ivan N. Marin ${ }^{1}$, Dmitry M. Palatov ${ }^{1,2}$ \\ Иван Н. Марин ${ }^{1}$, Амитрий М. Палатов ${ }^{1,2}$
}

\footnotetext{
${ }^{1}$ A.N. Severtsov Institute of Ecology and Evolution of RAS, Moscow 119071, Russia.

${ }^{2}$ Moscow State University, Leninskye gory, 1, Moscow, 119992 Russia.

E-mails: coralliodecapoda@mail.ru, triops@yandex.ru

${ }^{1}$ Институт экологии и эволюции им. А.Н. Северцова РАН, Москва 119071, Россия.

${ }^{2}$ Московский государственный университет, Ленинские горы, 1, Москва, 119992, Россия.
}

KEY WORDS: Crustacea, Amphipoda, diversity, relic, epigean, stygobiotic, Russia, Palaearctic.

КЛЮЧЕВЫЕ СЛОВА: Crustacea, Amphipoda, разнообразие, реликты, эпигейные, стигобионты, Россия, Палеарктика.

ABSTRACT. Two new Palaearctic genera are proposed within the family Crangonyctidae (Crustacea: Amphipoda), including species previously assigned to the Western Palearctic "Synurella dershavini"-group: Volgonyx gen.n. for Synurella dershavini Behning, 1928, and Pontonyx gen.n. for Synurella odessana Sidorov et Kovtun, 2015 and Synurella osellai Ruffo, 1972. New genera can be clearly distinguished from all Eurasian crangonyctid genera by a combination of morphological features, such as 1) a large elongated nonpigmented (troglomorphic) body; 2) males noticeably larger than females, with distinct sexual dimorphism in body size and morphology of uropod I; 3) absence of the calceoli on antenna II; and 4) more than 4 coupling hooks in retinacules of pleopods. Each of these genera is also characterized by several specific morphological features: greatly unequal rami of uropod I in males and a different number of coupling hooks in retinacules of pleopods (3-4 in females and 6-8 in males) in Volgo$n y x$ gen.n.; and the presence of characteristic terminal "squamous knob" on endopodite of uropod III, 5-6 coupling hooks in retinacules of pleopods and telson with a deep U-shaped notch reaching almost $1 / 3$ of its length in Pontonyx gen.n. A combination of morphological features and molecular genetic analysis based on COI mtDNA gene marker easily separates these new genera from the genus Synurella s.str., with the type species Synurella ambulans (F. Müller, 1846), as well as any of crangonyctid genera in both the Holarctic and Palaearctic. According to our phylogenetic reconstructions, Volgonyx gen.n. and Pontonyx gen.n. belong to the Stygobromus-clade, but they occupy wellisolated distant positions, which indicates the relic origin of these lineages, obviously correlated in time with the breakup of Laurasia in the Cretaceous (about 13560 Mya). Volgonyx dershavini (Behning, 1928) comb.n. is also re-described based on topotypic material and the neotype is selected, since the type material is now lost.

How to cite this paper: Marin I.N., Palatov D.M. 2021. Volgonyx gen.n. and Pontonyx gen.n., two new genera of the family Crangonyctidae (Crustacea: Amphipoda) from the southeastern Europe // Arthropoda Selecta. Vol.30. No.1. P.43-61, Supplement. doi: 10.15298/arthsel.30.1.05

РЕЗЮМЕ. В составе семейства Crangonyctidae (Crustacea: Amphipoda) предлагается выделение двух новых родов, включающих виды, ранее относимые к западно-палеарктической группе "Synurella dershavini": Volgonyx gen.n. для Synurella dershavini Behning, 1928 и Pontonyx gen.n. для Synurella odessana Sidorov et Kovtun, 2015 и Synurella osellai Ruffo, 1972. Новые роды можно четко отличить от других родов евразийских крангониктид по комбинации морфологических признаков, таких как 1) большое удлиненное непигментированное (трогломорфное) тело; 2) самцы заметно крупнее самок, с отчетливым половым диморфизмом, проявляющимся в размерах тела и морфологии уропода I; 3) отсутствие кальцеол на антеннах II; и 4) наличие более 4 крючков в ретинакулах плеопод. Также для каждого рода характерны несколько специфических морфологических особенностей: сильно разные ветви уропод I у самцов и разное количество сцепных крючков на ретинакулах плеопод (3-4 у самок и 6-8 у самцов) у Volgonyx gen.n.; наличие характерного терминального выступа на эндоподи- 
те уропод III, 5-6 сцепляющих крючков в ретинакулах плеопод и тельсон с глубоким U-образным вырезом, достигающим почти $1 / 3$ его длины, у Pontonyx gen.n. Сочетание морфологических признаков и молекулярно-генетического анализа на основе генного маркера COI мтДНК легко отделяет новые роды от рода Synurella s.str. с типовым видом Synurella ambulans (F. Müller, 1846), а также от любого из родов крангониктид. как в Голарктике, так и в Палеарктике. Согласно филогенетическим реконструкциям Volgonyx gen.n. и Pontonyx gen.n. принадлежат к кладе "Stygobromus-clade", но занимают хорошо изолированные отдаленные позиции, что указывает на их реликтовое происхождение, близкое ко времени развала Лавразии в меловом периоде (около 135-60 млн. лет назад). Также Volgonyx dershavini (Behning, 1928) comb.n. переописывается на основе топотипического материала и выделяется неотип, так как типовой материал ныне, по-видимому, утерян.

\section{Introduction}

The family Crangonyctidae Bousfield, 1973 consists of predominantly fresh-water (mostly groundwater or epigean) continental amphipods [Bousfield, 1973; Holsinger, 1978; Zhang, Holsinger, 2003; Lowry, Myers, 2013, 2017], closely related to the East Asian Pseudocrangonyctidae Holsinger, 1989 and the Iceland Crymostygidae Kristjánsson et Svavarsson, 2004 [Holsinger, 1994; Kristjánsson, Svavarsson 2004; Kornobis et al., 2011; Sidorov, Gontcharov, 2015]. Currently, 10 valid crangonyctid genera (Amurocrangonyx Sidorov et Holsinger, 2007 (1 species), Bactrurus Hay, 1902 (7 species), Crangonyx Spence Bate, 1859 (49 species), Diasynurella Behning, 1940 (1+ species), Eosynurella Martynov, 1931 (4 species), Lyurella Derzhavin, 1939 (2 species), Palearcticarellus Palatov et Marin, 2020 (5 species), Stygobromus Cope, 1872 (142 species), Stygonyx Bousfield et Holsinger, 1989 (1 species) and Synurella Wrześniowski, 1877 (14 species) [Palatov, Marin, 2020], with more than 220 species distributed in the Holarctic and Palaearctic are known (according to WoRMS database [Horton et al., 2020]).

It is assumed that the family originated before the final break-up of Laurasia at the Cretaceous [CopilaşCiocianu et al., 2019], while the discovered species richness of the family is the highest throughout North America [Holsinger, 1974, 1978; Zhang, Holsinger, 2003; Kornobis et al., 2012; Horton et al., 2020], the diversity in Eurasia is probably studied more poorly and fragmentarily [Decu et al., 2019]. Due to the specific ecology and life style, representatives of the family Crangonyctidae are characterized by narrowly localized, endemic and relict distribution in the Holarctic [Zhang, Holsinger, 2003; Svavarsson, Kristjánsson, 2006; Sidorov, Holsinger 2007; Kornobis et al., 2012; Copilaş-Ciocianu et al., 2019], while they are less di- verse, but are more widely distributed in the Palaearctic [Palatov, Marin, 2020]). Moreover, recent molecular and morphological studies do not confirm the monophyly of three largest and widespread genera: Crangonyx, Stygobromus and Synurella [Kornobis et al., 2011; Copilaş-Ciocianu et al., 2019] with the reflected geographical proximity of species [Copilaş-Ciocianu et al., 2019; Palatov, Marin, 2020]. Thus, the natural system of the family is most likely based on geographic distribution, while morphological features can be considered as secondary.

Eight species from three crangonyctid genera are currently known from the northwestern Palearctic, including three species still referring to Synurella "dershavini"-group [Sidorov, Kovtun, 2015; Takhteev et al., 2015; Palatov, Marin, 2020]: Synurella donensis Martynov, 1919 described from small, barely oozing limestone spring in the valley of the Kizyterinka river outside the Nakhichevan-na-Donu district of the city of Rostov-on-Don in the lower course of the Don River [Martynov, 1919] and probably distributed at the boundary of the north-eastern platform, the eastern edge of the Ukrainian Shield $\left(47^{\circ} 13^{\prime} 53.0^{\prime \prime} \mathrm{N} 39^{\circ} 45^{\prime} 25.0^{\prime \prime} \mathrm{E}\right)$ (Pliocene) [Sidorov, Kovtun, 2015]; Synurella dershavini Behning, 1928 known from springs in the city of Saratov [Behning, 1928] and probably distributed in the Ryazan-Saratov flexure of the north-eastern platform $\left(51^{\circ} 24^{\prime} 42.5^{\prime \prime} \mathrm{N} 45^{\circ} 45^{\prime} 27.8^{\prime \prime} \mathrm{E}\right)$ (Lower Cretaceous) [Sidorov, Kovtun, 2015]; Synurella osellai Ruffo, 1972 described from Tirebolu District near Giresun, and presently known also from Ordu Trabzon Provinces along the Black Sea coastline of Turkey [Ruffo, 1972; Özbek, 2018]; and Synurella odessana Sidorov et Kovtun, 2015 described from subterranean water resources in catacombs under Odessa, Ukraine at northwestern coast of the Black Sea $\left(46^{\circ} 28^{\prime} 54.0^{\prime \prime} \mathrm{N} 30^{\circ} 42^{\prime} 15.2^{\prime \prime} \mathrm{E}\right)$ [Sidorov, Kovtun, 2015]. According to Sidorov \& Kovtun [2015], the present distribution of the "dershavini"-group in the Volga-Black Sea basin is probably related to the formation of the paleo-basins of the Don and Volga rivers of the European part of Russia [Sidorov, Kovtun, 2015: fig. 1], and its geographic distribution was significantly changed after the reconfiguration of the river network over the time. At the same time, morphogenetic studies of the species from the "dershavini"'-group suggest their polyphyly as well as clear difference from the genus Synurella s.str. (with the type species - Synurella ambulans (F. Müller, 1846)) [Sidorov, Kovtun, 2015; see below].

The main aim of this paper is a thorough re-description of Synurella dershavini Behning, 1928, based on topotypic material, with the selection of neotype (since the original material is now considered as lost), and the separation of the species into a new genus. In addition, a new genus is also proposed for Synurella odessana Sidorov et Kovtun, 2015 and Synurella osellai Ruffo, 1972 based on their original and later descriptions [Ruffo, 1972; Sidorov, Kovtun, 2015; Özbek, 2018]. 
Table 1. The list of sampling stations near the city of Saratov on the upper (right) bank of the Volga River, where amphipods were found.

Таблица 1. Список станций в окрестностях города Саратов на высоком (правом) берегу реки Волга, где были собраны амфиподы.

\begin{tabular}{|c|c|c|c|}
\hline \multicolumn{2}{|r|}{ Locality/Station } & Date & Coordinates \\
\hline 1 & $\begin{array}{l}\text { Spring on the southern slope of the Lysaya mount (the city } \\
\text { of Saratov) (the station mostly close to the type locality) }\end{array}$ & 6.08 .2020 & $\begin{array}{l}51^{\circ} 31^{\prime} 24.51^{\prime \prime N} \\
45^{\circ} 56^{\prime} 04.96 " \mathrm{E}\end{array}$ \\
\hline 2 & $\begin{array}{l}\text { Spring in the valley of the Petrovka stream, at the bottom of } \\
\text { a deep forest ravine (about } 1.3 \mathrm{~km} \text { above the village of } \\
\text { Burkin Buerak) }\end{array}$ & 5.08 .2020 & $\begin{array}{l}51^{\circ} 25^{\prime} 15.6^{\prime \prime N} \\
45^{\circ} 43^{\prime} 52.2^{\prime \prime} \mathrm{E}\end{array}$ \\
\hline 3 & $\begin{array}{l}\text { Spring in the valley of the Petrovka stream, the bottom of a } \\
\text { deep forest ravine (the western border of the village of } \\
\text { Burkin Buerak) }\end{array}$ & 5.08 .2020 & $\begin{array}{l}51^{\circ} 24^{\prime} 58.88^{\prime \prime N} \\
45^{\circ} 44^{\prime} 48.47^{\prime \prime} \mathrm{E}\end{array}$ \\
\hline 4 & Spring ("White Spring") at the chapel of Paraskeva Friday & 6.08 .2020 & $\begin{array}{l}51^{\circ} 48^{\prime} 53.08^{\prime \prime N} \\
46^{\circ} 25^{\prime} 59.78^{\prime \prime} \mathrm{E}\end{array}$ \\
\hline 5 & $\begin{array}{l}\text { Spring near the chapel of "Beautiful spring" near the village } \\
\text { of Commune } 3\end{array}$ & 7.08.2020 & $\begin{array}{l}51^{\circ} 51^{\prime} 34.62^{\prime \prime N} \\
46^{\circ} 22^{\prime} 48.57 " \mathrm{E}\end{array}$ \\
\hline 6 & $\begin{array}{l}\text { Spring in the valley of the Nazarovka stream (the western } \\
\text { border of the village of Babanovka) }\end{array}$ & 6.08 .2020 & $\begin{array}{l}51^{\circ} 13 ' 32.79^{\prime \prime} \mathrm{N} \\
45^{\circ} 43^{\prime} 05.56^{\prime \prime} \mathrm{E}\end{array}$ \\
\hline
\end{tabular}

\section{Material and Methods}

Amphipods were collected using a hand net in various epigean water resources of the city of Saratov $\left(51^{\circ} 31^{\prime} 59.2^{\prime \prime} \mathrm{N}\right.$ $\left.46^{\circ} 02^{\prime} 03.0^{\prime \prime} \mathrm{E}\right)$, very close to the type locality reported for Synurella dershavini by Behning [1928], and along the upper (right) bank of the Volga river (see Table 1) in September 2020. Animals were photographed alive using a digital camera Canon G16 and then fixed in 90\% ethanol. The body length (bl., mm), the dorsal length from the distal margin of head to the posterior margin of telson, without the length of uropod 3 and antennas, is used as a standard measurement. Photographs of body parts were made with a digital camera attached to light microscope Olympus ZX10 and Olympus CX21. Photographs of alive coloration of animals in situ were made using Canon G16 digital camera. Scanning electron microscopy (SEM) photos were made in the Orlov Paleontological Museum of the Paleontological Institute of Russian Academy of Sciences using Vega3 Tescan microscope. The neotype and additional material are deposited at the collection of Zoological Museum of Moscow State University, Moscow, Russia (ZMMU) and Laboratory of Ecology and Evolution of Marine Invertebrates of A.N. Severtsov Institute of Ecology and Evolution of Russian Academy of Sciences, Moscow, Russia (LEMMI).

Cytochrome c oxidase subunit I (COI) mtDNA was used as one of the most informative gene markers for genetic studies at population and species level to confirm the phylogenetic relationships of the studied species [Avise, 1993; Hebert et al., 2003a, b]. Total genomic DNA was extracted from muscle tissue using the innuPREP DNA Micro Kit (AnalitikJena, Germany). The COI mtDNA gene marker was amplified with the help of the universal primers LCO1490 (5'-GGTCAACAAATCATAAAGATATTGG-3') and HC02198 (5'-TAAACTTCAGGGTGACCAAAAAATCA3') [Folmer et al., 1994]. PCR products were performed on amplificator T100 (Bio-Rad, USA) under the following con- ditions: initial denaturation at $96{ }^{\circ} \mathrm{C}$ for $1.5 \mathrm{~min}$ followed by 42 cycles of $95^{\circ} \mathrm{C}$ for $2 \mathrm{~min}, 49^{\circ} \mathrm{C}$ for 35 seconds, and $72{ }^{\circ} \mathrm{C}$ for $1.5 \mathrm{~min}$, followed by chain extension at $72{ }^{\circ} \mathrm{C}$ for $7 \mathrm{~min}$. The volume of $10 \mathrm{uL}$ of reaction mixture contained $1 \mathrm{uL}$ of total DNA, $2 \mathrm{uL}$ of 5xPCR mix (Dialat, Russia) and $1 \mathrm{uL}$ of each primer. The amplification products were separated by using gel electrophoresis of nucleic acids on a $1.5 \%$ agarose gel in 1xTBE, and then stained and visualized with $0.003 \%$ EtBr using imaging UV software. DNA nucleotide sequences were determined using Genetic Analyzer ABI 3500 (Applied Biosystems, USA) and BigDye 3.1 (Applied Biosystems, USA) with direct and reverse primers. Dataset of aligned sequences of COI mtDNA gene markers, about 658 base pairs in length used in the study were taken from GenBank (NCBI) and original data.

Consensus of complementary sequences was obtained with MEGA 7.0. The best evolutionary substitution model was determined using MEGA 7.0 and jModeltest2.1.141. A phylogenetic analysis was conducted using PhyML 3.0 (http:/ /www.atgc-montpellier.fr/phyml/) [Guindon et al., 2010] and RAxML (https://raxml-ng.vital-it.ch) [Kozlov et al., 2019] with several models based on BIC (Bayesian Information Criterion) and AIC (Akaike Information Criterion). The trees with the higher bootstrap probability were used for graphic display of relationships within the family. Bootstrap support is presented for ML analysis. Pairwise genetic divergences (p-distances) was calculated based on COI sequences using MEGA 7.0 with the Kimura 2-Parameter (K2P) model of evolution [Kimura, 1980].

\section{Results}

\section{PHYLOGENETIC RECONSTRUCTION}

The intraspecific pairwise genetic distances ( $p$-distances) in studied populations of Volgonyx dershavini 
Table 2. Pairwise genetic (COI mtDNA) distances ( $p$-distances) and estimated node age (Mya) (after Gay-Haim et al. [2018] suggested COI mtDNA substitution rates as 0.0077 substitution/Mya) of Volgonyx dershavini (Behning, 1928) comb.n. $(\mathrm{n}=6)$ and Pontonyx odessana (Sidorov et Kovtun, 2015) comb.n. $(n=2)$ and other genera of the family Crangonyctidae (from GenBank (NCBI) database).

Таблица 2. Попарные генетические (COI мтДНК) дистанции ( предположительный возраст клады (млн.) (по Gay-Haim et al. [2018] предложившей значения COI мт ДНК замен как 0.0077 замен/млн) для Volgonyx dershavini (Behning, 1928) comb.n. (n=6) и Pontonyx odessana (Sidorov et Kovtun, 2015) comb.n. $(\mathrm{n}=2)$, а также других родов семейства Crangonyctidae (на основе данных GenBank (NCBI)).

\begin{tabular}{|l|c|c|}
\hline Taxon/Genus & $\begin{array}{c}\text { Calculated p-distances } \\
\text { Volgonyx / Pontonyx }\end{array}$ & $\begin{array}{c}\text { Estimated node age (Mya) } \\
\text { Volgonyx / Pontonyx }\end{array}$ \\
\hline Volgonyx/Pontonyx & 0.277 & 36.05 \\
\hline Eosynurella & $0.308 / 0.257$ & $40.07 / 33.71$ \\
\hline Stygobromus s.str. & $0.309 / 0.257$ & $40.07 / 33.38$ \\
\hline Synurella s.str. & $0.311 / 0.308$ & $40.39 / 39.98$ \\
\hline Crangonyx_islandicus & $0.312 / 0.289$ & $40.53 / 37.48$ \\
\hline Diasynurella & $0.315 / 0.261$ & $40.97 / 33.88$ \\
\hline Lyurella & $0.328 / 0.315$ & $42.61 / 40.99$ \\
\hline Amurocrangonyx & $0.330 / 0.264$ & $42.82 / 34.27$ \\
\hline Stygobromus gr.2 & $0.330 / 0.290$ & $42.96 / 37.67$ \\
\hline Palearcticarellus & $0.343 / 0.278$ & $44.50 / 36.08$ \\
\hline Bacturus & $0.340 / 0.283$ & $44.16 / 36.72$ \\
\hline Synurella USA & $0.361 / 0.298$ & $46.88 / 38.70$ \\
\hline Crysmostygius & $0.365 / 0.361$ & $47.38 / 46.87$ \\
\hline
\end{tabular}

(Behning, 1928) comb.n. is very low, being about 0.008 substitutions per 100 nucleotides $(0.8 \%)$ between most distant localities (stations) (Stations 4, 6). Such data shows that the gene flow is occurring between specimens from these localities, and they are not completely isolated at present.

The interspecific pairwise genetic distances $(p$ distances) between Volgonyx dershavini (Behning, 1928) comb.n. and Pontonyx odessana (Sidorov et Kovtun, 2015) comb.n. and other crangonyctid species/genera exceed $0.308 / 0.257$ substitutions per 100 nucleotides $(30.8 \% / 25.7 \%)$, respectively (Tables 1 , 2; Fig. 1), while the estimated divergence time (node ages) exceed 40 Mya and 33 Mya, respectively (after Guy-Haim et al. [2018] suggested 0.0077 substitution/Mya for molecular clock calibration based on COI mtDNA gene marker for Typhlocaris spp.), which clearly support long-time separation and isolation of these lineages.

The reconstruction (tree) of molecular phylogeny (by COI mtDNA gene marker) of the family Crangonyctidae suggested three different scenarios (trees) with the higher bootstrap probability (PP) of the main clades (GTR+G+I (BIC) (Fig. 1A), AIC-SH (Fig. 1B) and AIC-Chi (Fig. 1C)). The best-selected model is $\mathrm{GTR}+\mathrm{G}+\mathrm{I}$ (BIC) (Fig. 1A). In all scenarios, the new genera occupy and isolated positions (Fig. 1). The position of Palearctic Volgonyx dershavini (Behning, 1928) comb.n. is always referring within the
Stygobromus-clade as sister taxa to the genus Holarcrtic Stygobromus s.str. and Stygobromus gr.1, Iceland Crangonyx islandicus, and Palearctic Volgonyx dershavini (Behning, 1928) comb.n. is presented within the Stygobromus-clade as sister taxa to Pontonyx odessana (Sidorov et Kovtun, 2015) comb.n. in the (AIC-Chi) model (Fig. 1C). At the same time, Pontonyx odessana (Sidorov et Kovtun, 2015) comb.n. with the Palaearctic (Lesser Caucasian) Diasynurella are considered as sister taxa to the Stygobromus-clade, including Holarcrtic Stygobromus s.str. and Stygobromus gr.1, Iceland Crangonyx islandicus and Palearctic Volgonyx dershavini (Behning, 1928) comb.n. in the GTR+G+I (BIC) model (the best-selected model for the reconstruction). In other scenarios the position of Pontonyx odessana (Sidorov et Kovtun, 2015) comb.n. is considered as sister taxa to the related Stygobromus-clade (Fig. 1B) and together with Volgonyx dershavini (Behning, 1928) comb.n. as sister taxa to the genus Stygobromus s.str. and Crangonyx islandicus within the Stygobromus-clade (Fig. 1C). All these scenarios suggest that lineages of Volgonyx dershavini (Behning, 1928) comb.n. and Pontonyx odessana (Sidorov et Kovtun, 2015) comb.n. separated from related genera of the Stygobromus-clade close to the time of the breakup of Laurasia at the Cretaceous period (about 135-60 Mya), since related genera are known from the Holarctic, Iceland and Palearctic, finally separated about 60 Mya. 


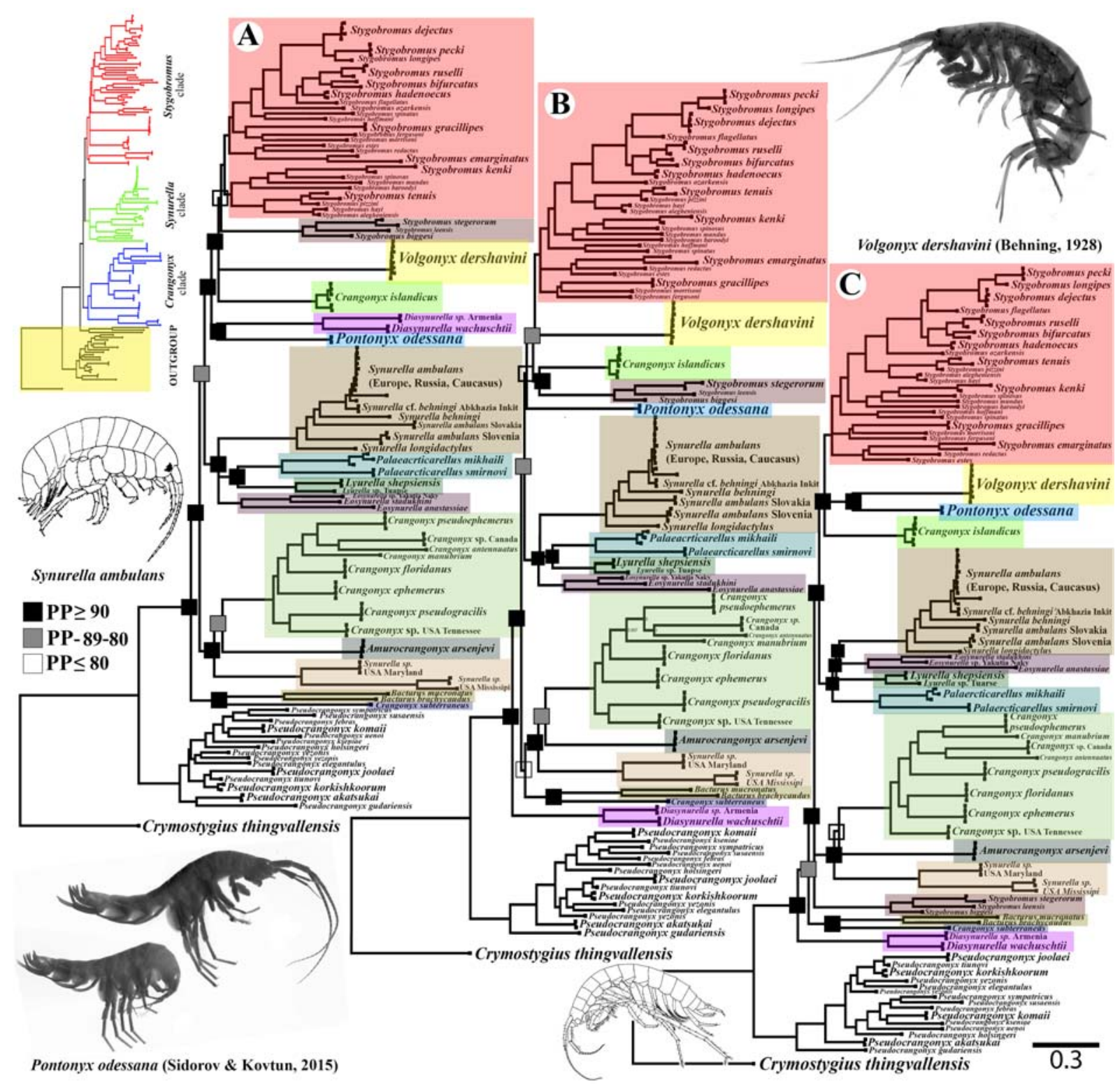

Fig. 1. Different reconstruction (tree) of molecular (COI mtDNA gene marker) phylogenetic scenarios (A - GTR+G+I (Bayesian Information Criterion (BIC)), B - Akaike Information Criterion (AIC)-aLRT SH-like fast likelihood-based method (AIC-SH) and C AIC-aLRT Chi2-based fast likelihood-based method (AIC-Chi)) of the family Crangonyctidae with the higher bootstrap probability (with the related Pseudocrangonyctidae and Crymostygidae as an outgroup) (sequences from NCBI (GenBank)). Color indicates different genera; nodes are marked with the support based on ML (Maximum Likehood) algorithm. Drawing and photo credits: Synurella ambulans - from Arbačiauskas [2008]; Pontonyx odessana comb.n. - from Sidorov \& Kovtun [2015]; Crymostygius thingvallensis — from Kristjánsson \& Svavarsson [2004]. High resolution version see in Supplement.

Рис. 1. Различные реконструкции (деревья) молекулярных (COI mtDNA gene marker) филогенетических сценариев (А GTR+G+I (Информационный критерий Байеза (BIC)), B - информационный критерий Айкаике (AIC)-aLRT SH-like быстрый метод правдоподобия (AIC-SH) и C - AIC-aLRT Chi2-based быстрый метод правдоподобия (AIC-Chi)) семейства Crangonyctidae с максимальной поддержкой клад (с родственными Pseudocrangonyctidae и Crymostygidae в качестве аутгруппы) (сиквенсы из NCBI (GenBank)). Цветом обозначены различные рода; поддержка клад по алгоритму ML (максимального правдоподобия). Рисунки и фотографии: Synurella ambulans — из Arbačiauskas [2008]; Pontonyx odessana comb.n. — из Sidorov \& Kovtun [2015]; Crymostygius thingvallensis - из Kristjánsson \& Svavarsson [2004]. Версию в высоком разрешении см. Supplement. 


\section{TAXONOMIC PART}

Order Amphipoda Latreille, 1816

Suborder Senticaudata Lowry et Myers, 2013

Infraorder Gammarida Latreille, 1802

Superfamily Crangonyctoidea Bousfield, 1973

Family Crangonyctidae Bousfield, 1973

\section{Genus Volgonyx Marin et Palatov gen.n.}

DIAGNOSIS. Size relatively large, up to $7-8 \mathrm{~mm}$ in females, and $10 \mathrm{~mm}$ - in males, with marked sexual dimorphism in uropod I. Body smooth, not pigmented (troglomorphic), uronites completely fused, without dorsal spines; head without rostrum, lateral lobe rounded anteriorly; black eye (ommatidia) invisible or completely reduced, large yellow spots present on head. Antenna I longer than antenna II; primary segments of flagellum with transparent aesthetascs; accessory flagellum 2-segmented. Antenna II without calceoli in males. Upper lip rounded apically, margin not incised. Mandible with well-developed incisor process and lacinia mobilis and underlying row of spines; molar process triturative; palp 3-segmented. Maxilla I: inner plate with 10 12 long plumose setae apically; outer plate with 7 mostly serrate spines apically; palp 2-segmented, with short setae and spines apically. Maxilla II: inner plate oval, broader than outer plate, with oblique row of long plumose setae along inner margin; both plates with numerous setae apically. Maxilliped: inner plate with numerous spines and stifflike setae apically; outer plate with short stiff-like setae on apex and along inner margin; palp 4-segmented. Lower lip with well-developed outer lobes; inner lobes small; lateral processes rather short, usually narrowly rounded distally. Gnathopods I-II robust, unequal in size and dissimilar shape (GnI smaller GnII); palm of GnI mostly quadrate in shape, while palm of GnII close to tear-like shape; palmar margin in both gnathopods with a double row of typically distally notched spine teeth. Pereopods III-IV mostly subequal, pereopod V shorter than pereiopods VI and VII. Coxal gills on pereopods II-VII moderately small, pedicellate, oblong. Posterior corners of pleonal plates usually rounded, posterior margins usually with several short setae, ventral margins with small spines, sometimes reduced. Pleopods biramous, subequal in length, with 3-4 coupling hooks in retinacules in females, and 6-8 hooks in retinacules in males. Uropods I-II biramous, rami and peduncles armed with strong simple spines; uropod I greatly dimorphic in males, with inner ramus about 3-4 times larger than outer one, while rami equal and about as long as the length of peduncle in females; uropod II with equal rami, about as long as the length of peduncle; uropod III uniramous, with short 2-segmented ramus. Telson quadrate, distal margin almost straight, with small but distinct distal notch.

INCLUDED SPECIES. Presently, the genus is monotypic, with the only type species - Volgonyx dershavini (Behning, 1928) comb.n.

ETYMOLOGY. The genus is named after its distribution in the Volga river basin.

DIFFERENTIAL DIAGNOSIS. According to phylogenetic reconstructions based on COI mtDNA, Volgonyx gen.n. belongs to the Stygobromus-clade (Fig. 1), occupying a wellisolated distant position, being very distant from all other Eurasian crangonyctid genera (Fig. 1). Molecular-genetic methods are better applicable for phylogenetic analysis as compared to morphological methods in the amphipods [Copilaş-Ciocianu et al., 2019]. It was difficult to to separate the genera within the family Crangonyctidae based on morphology only [Sidorov, Holsinger, 2007].

At the same time, Synurella s.l. "dershavini"-group that previously included $S$. dershavini, $S$. donensis, $S$. osellai and $S$. odessana [Sidorov, Kovtun 2015] is distinctly polyphyletic, based on morphological and molecular genetic data (Fig. 1, see below). Synurella donensis clearly belongs to the genus Synurella s.str., while S. odessana and S. osellai belong to Pontonyx gen.n. (see below).

Based on morphology the new genus can be also distinctly separated from the Western Eurasian genus Synurella s.str. (with the type species Synurella ambulans (F. Müller, 1846)) [Sidorov, Palatov, 2012] by the following features: 1) males distinctly larger than females (vs. females are distinctly larger than males in $S$. ambulans); 2) not pigmented body and the absence of black-pigmented eyes (ommatidia) (vs. pigmented body and black-pigmented eyes (ommatidia) characteristic for $S$. ambulans); 3) absence of calceoli on antenna II (vs. present in S. ambulans); 4) epimeral plates IIII blunty produced posteroventrally with small subdistal pointed protrusions (vs. distinctly sharply produced in $S$. ambulans); 5) pleopods with 3-4 (in females) - 6-8 (in males) coupling hooks in retinacules (vs. only 2 hooks in retinacules in both sexes in $S$. ambulans); 6) greatly unequal rami of uropod I in males (vs. similar rami, equal to peduncle, in both sexes of $S$. ambulans; and 7) almost quadrate telson with feebly developed distal notch (vs. distinctly rectangular telson with well-marked deep distal notch in $S$. ambulans).

From the Western Siberian Palearcticarellus (with the type species Palearcticarellus smirnovi Palatov et Marin, 2020) [Sidorov et al., 2010; Palatov, Marin, 2020], the new genus can be separated by: 1) a well-developed distal segment of accessory flagellum of antenna I (vs. mostly reduced in Palearcticarellus); 2) gnathopods I-II different in size/ shape, especially smaller GnI (vs. almost equal gnathopods I-II in Palearcticarellus); 3) fused uronites (free in Palearcticarellus); 4) greatly unequal rami of uropod I in males (vs. similar rami, equal to peduncle, in Palearcticarellus (only females are known)); and 5) distinctly smaller ramus of uropod III.

From the Caucasian genus Lyurella (with the type species Lyurella hyrcana Derzhavin, 1939 [Derzhavin, 1939; Sidorov, 2015]), the new genus can be separated by 1) nonpigmented body and mostly reduced eyes (ommatidia) (vs. pigmented orange body and large well-developed black ommatidia in Lyurella); 2) epimeral plates I-III blunty produced posteroventrally with small subdistal pointed protrusions (vs. sharply produced in Lyurella); 3 ) absence of additional spines on dactyli of pereopods III-VII (vs. present in Lyurella); 4) 2-segmented outer rami of uropod III (1-segmented in Lyurella); 5) strong sexual differences in the number of coupling hooks in retinacules of pleopods (3-4 in females and 6-8 in males) (vs. equal number of hooks in retinacules of pleopods in males and females of Lyurella, with 3 hooks in L. shepsiensis Sidorov, 2015 and 4 hooks in L. hyrcana); 7) greatly unequal rami of uropod I in males (vs. similar rami, equal to peduncle, in Lyurella).

From the Beringian (Eastern Eurasian and Alaskan) Eosynurella [Martynov, 1931] and the Lesser Caucasian Diasynurella [Behning, 1940] it can be separated by: 1) nonpigmented body and mostly reduced eyes (ommatidia) (vs. pigmented orange body and large well-developed black eyes 
in Eosynurella, but completely reduced in Diasynurella); 2) longer antenna I-II and different shape of coxal gills [Martynov, 1931]; 3) greatly unequal rami of uropod I in males (vs. similar rami, equal to peduncle, in Eosynurella and Diasynurella); 4) epimeral plates I-III blunty produced posteroventrally with small subdistal pointed protrusions (vs. sharply produced in Eosynurella and Diasynurella); and 5 ) the presence of 3-8 hooks in retinacules of pleopods (vs. usually only 2 hooks in retinacules of pleopods in Eosynurella and Diasynurella).

From the Far-Eastern Amurocrangonyx [Sidorov, Holsinger, 2007], and all North American crangonyctid genera, such as Stygobromus, Crangonyx, Stygonyx and Bacturus, the new genus can be clearly separated by: 1) presence of coxal gills $7 ; 2$ ) blunt posteroventral margins of epimeral plates I-III; 3) presence of 3-8 hooks in retinacules of pleopods; 3) greatly unequal rami of uropod I in males; 4) uropod III uniramous, with small distal article, about $1 / 4$ of the length of peduncle; and 5) telson with feebly developed distal notch. These genera are very distant according to molecular genetic studies (see above).

DISTRIBUTION. The type species of the genus is presently known only from the wells and springs along the upper (right) bank of the Volga River in the city of Saratov and its vicinity. It is possible that the area of the genus distribution is much wider than presently known.

\section{Volgonyx dershavini (Behning, 1928) comb.n.} Figs 1-5.

MATERIAL EXAMINED. Neotype: male (bl. $11 \mathrm{~mm}$ ), ZMMU $\mathrm{Mb}-1170$, spring (rheokren) on the southern slope of the Lysaya Mount in the city of Saratov, $51^{\circ} 31.409^{\prime} \mathrm{N} 45^{\circ} 56.083^{\prime} \mathrm{E}$, coll. D. Palatov, I. Marin \& V. Maryinsky, 6 September 2020.

Other material: female (bl. $8 \mathrm{~mm}$ ), ZMMU Mb-1171, same locality and data as neotype; 2 males (bl. $8 \mathrm{~mm}$ ), ZMMU Mb-1172, same locality and data as neotype; 3 females (bl. $7 \mathrm{~mm}$ ), ZMMU $\mathrm{Mb}-1173$, same location and collectors as neotype.

DIAGNOSIS. Both males and females are known, with well-marked sexual dimorphism in uropod I, males are larger. Large sized (up to $10.0 \mathrm{~mm}$ ) stygobiotic species. With reduced ommatidia, but well marked yellow eyes spots on head. Gnathopods I-II well-developed, dissimilar in size and unequal in shape, armed with a double row of numerous robust setae along palmar margins. Coxal gills present on coxal segments II-VII. Pleopods I-III with 3-4 (in females) and 7-8 (in males) coupling hooks in retinacules of pleopods. Uropod I with greatly dissimilar rami, inner ramus about 3-4 times larger than outer one in males; rami of uropod I are equal and similar to peduncle in females. Uropod III small, shorter than telson, uniramous; peduncle about 3.5-4 times longer than ramus in length, ramus with 3-4 apical robust spines. Telson rectangular, about 1.2 times longer than broad; distal margin with shallow U-shaped distal notch, each lobe armed with 5-6 distal spines and some plumose submarginal setae.

DESCRIPTION. Male (Fig. 2a, b): $11 \mathrm{~mm}$ and female 7-8 mm long. Eyes (ommatidia) invisible, probably reduced, almost all individuals may show yellow pigment spots on head in-situ (Fig. 2a), and black dots (ommatidia) present on head in fixed specimens (Fig. 2a). Inter-antennal lobe wide, bluntly rounded anteriorly (Fig. 8b).

Antenna I (Figs $3 a, 7 a$ ) is about $60-70 \%$ of the body length, about 2.0X longer than antenna II; primary flagellum with 24 segments in males and 18-19 in females, with aesthetascs on distal segments, shorter than respective seg- ments (Fig. 8a); accessory flagellum 2-segmented (Fig. 3b), distal segment little short to basal, overreaching the segment of the main flagellum.

Antenna II (Fig. 3c, d): gland clone distinct; peduncle about 2.0X longer than flagellum, with robust setae tightly covering segments 3 and 4, peduncle of segment 4 subequal to ones of segment 5 in length; flagellum 7 (female) - 10 (male)-segmented; calceoli absent on peduncle and flagellum.

Mandible (Fig. 4c-f): left mandible incisor 5-dentate, lacinia mobilis 5-dentate, with 6-7 robust plumose accessory setae; molar process with 1 seta (Figs. $4 d$ ). Right mandible incisor 4-dentate, lacinia mobilis bifurcate, both lobes with numerous protuberances; underlying with a row of 6-7 robust plumose setae; molar process similar to left mandible (Figs. 4e). Palp 3-segmented, segment 2 with 12-13 setae; segment 3 about 3-4 times longer than wide, with oval margins, with $12-15$ separate D setae, 4 separate E setae, 3 separate $\mathrm{C}$ setae and 2-3 separate A setae, lacking both B setae.

Upper lip (Fig. 4b): oval, elongated, apical margin with numerous small fine setae.

Lower lip (Fig. 4a): inner lobes well developed.

Maxilla I (Figs $4 g, h$ ): inner plate with 10-12 plumose marginal setae, outer plate with 7 apical comb-spines; palp 2-segmented, distal segment pubescent, about $1.5 \mathrm{X}$ of the length of basal segment, apical margin of distal segment with 10 simple and 2 subdistal robust setae.

Maxilla II (Fig. 4i): inner, outer plates covered in pubescent setae; outer plate smaller than inner plate, weakly narrowing distally, with 12 apical setae; inner plate narrowing slightly distally, with 10-12 simple and 7-11 plumose facial apical setae.

Maxilliped (Fig. 4j): inner plate much shorter than outer plate, with 5 spines, 10-11 plumose setae along apical margin and row of 6-7 simple submarginal setae, surface of plate covered in fine pubescence; outer plate with 23-25 marginal and 16-18 submarginal simple setae; palp 4-segmented, segment 1 with 2-3 setae, segment 2 with $30-32$ marginal setae, segment 3 setaceous with numerous marginal/submarginal setae; dactylus with 1 outer and 2-3 inner setae.

Gnathopod I: smaller than gnathopod II (GnI/GnII as 0.6/1 in length). Male (Fig. 3e): coxal plate weakly expanded distally, distally rounded, with 3-7 apical and numerous facial setae; width/depth ratios are 1.1; basis width/length is $0.44 / 1$, with 7-8 long simple setae inserted along posterior margin and 5-6 long simple setae inserted along anterior margin; ischium with 8-10 plumose setae; merus with 1618 distal setae; carpus is 0.58 of length of basis and 0.87 of length of propodus, slightly shorter than propodus, with 10 large separate simple setae and a group of serrated setae in anterior margin and 2 groups of serrated setae in posterior margin; propodus 1.2-1.3X longer than broad, with 4 groups (with 2-3 setae each) in anterior margin and 4 groups setae in posterior margin; distal margin of palm almost straight, slightly oblique, with double row of 8 inner and 7 outer bifurcate robust setae; palm groove (depression), where dactylus enters, with 5 inner robust setae, 1 large and 4 smaller robust outer setae (Fig. 3f); dactylus with 2-3 outer and 5 inner setae.

Female (Figs $7 b, 8 e$ ): coxal plate distally rounded, with 5 apical and numerous facial setae; width/depth ratios are 1.4; basis width/length is 0.40 , with 6 long simple setae inserted along posterior margin and 3 long simple setae inserted along anterior margin; ischium with $8-10$ plumose 

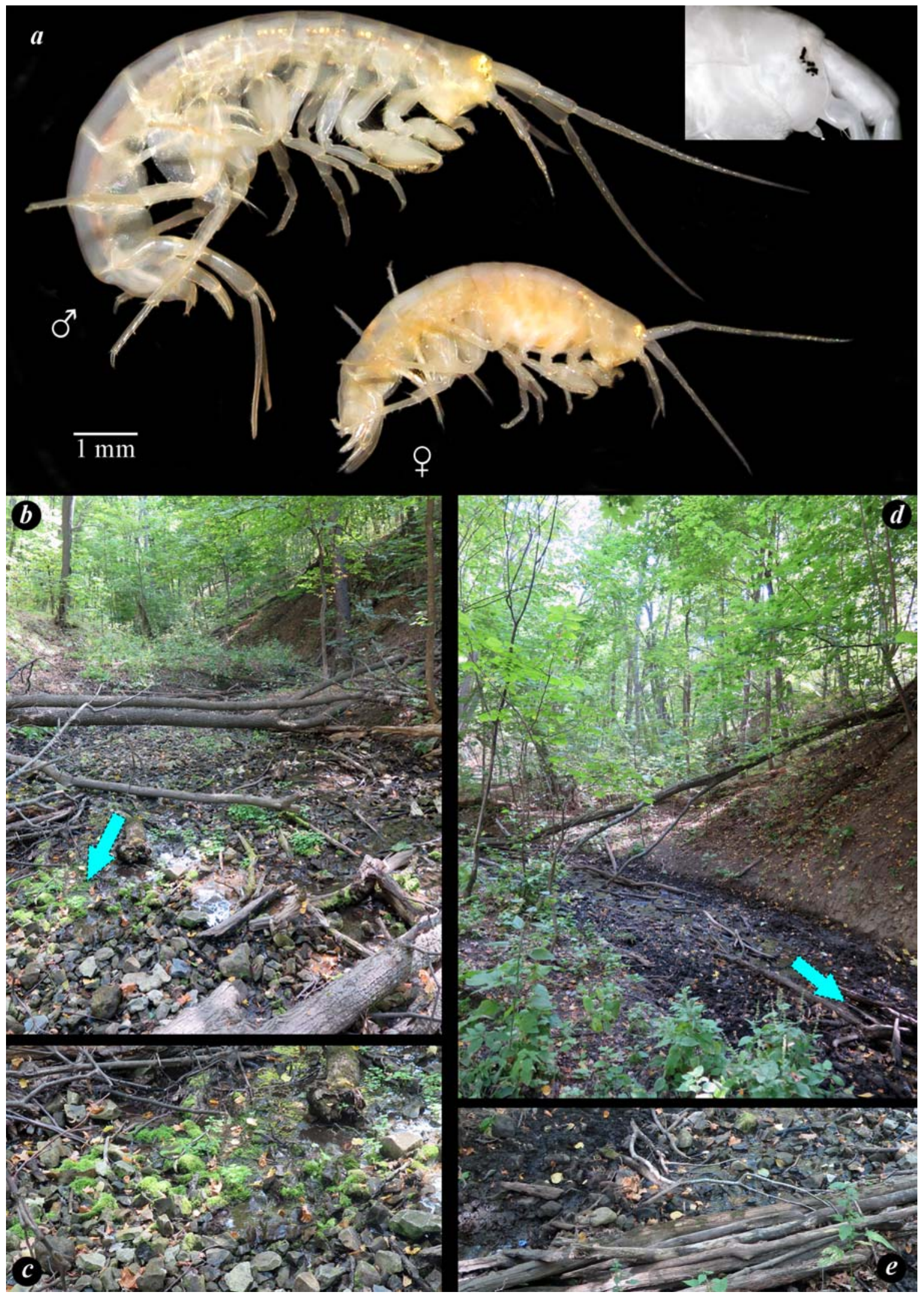

Fig. 2. Alive coloration $(a)$ and habitat (b-e) of Volgonyx dershavini (Behning, 1928) comb.n. in springs along the upper (right) bank of the Volga River near the city of Saratov.

Рис. 2. Прижизненная окраска (a) и местообитания (b-e) Volgonyx dershavini (Behning, 1928) comb.n. в родниках вдоль высокого (правого) берега реки Волги в районе г. Саратова. 


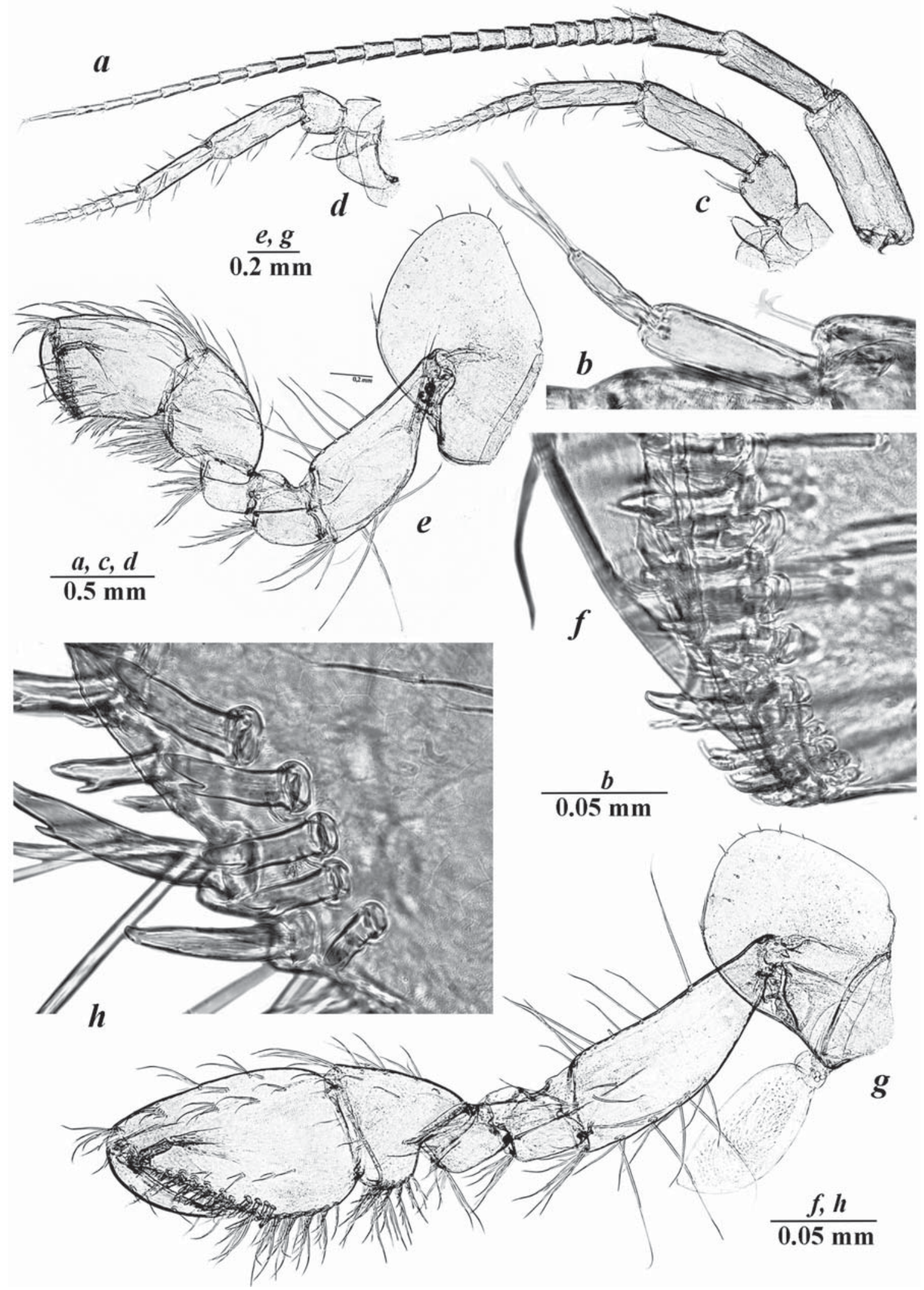

Fig. 3. Volgonyx dershavini (Behning, 1928) comb.n., male $(a-c, e-h)$, female $(d): a-$ antenna I; $b$ - accessory flagellum of antenna $1 ; c, d$ - antenna II; $e$ - gnathopod I; $f$ - palmar margin of chela of GnI; $g$ - gnathopod II; $h$ - palmar margin of chela of GnII.

Рис. 3. Volgonyx dershavini (Behning, 1928) comb.n., самец $(a-c, e-h)$, самка $(d): a-$ антенна I; $b-$ добавочный жгутик антенны $1 ; c, d$ - антенна II; $e$ - гнатопод I; $f$ - пальмарный край клешни GnI; $g$ - гнатопод II; $h$ - пальмарный край клешни GnII. 

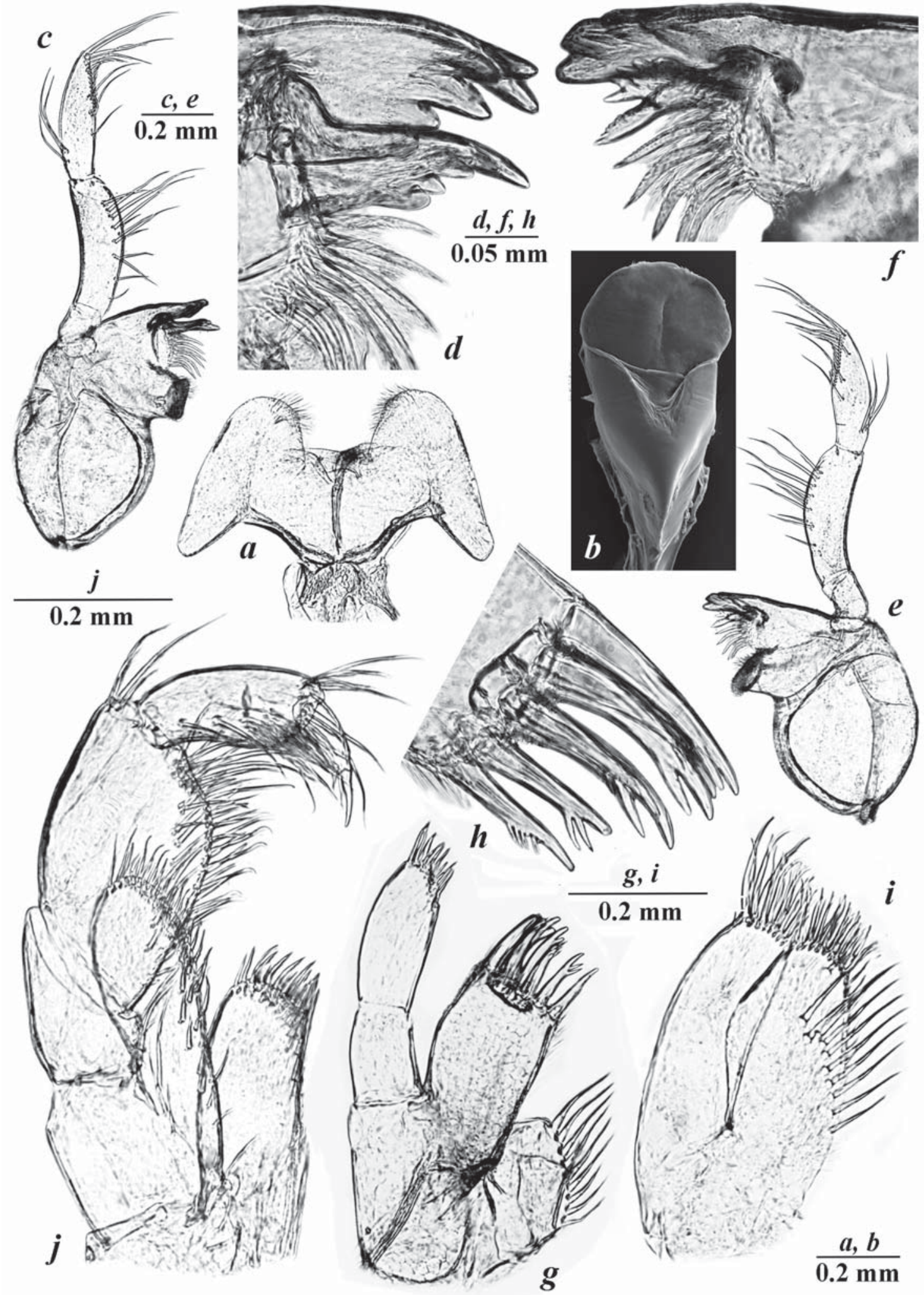

$\frac{g, i}{2 \mathrm{~mm}}$
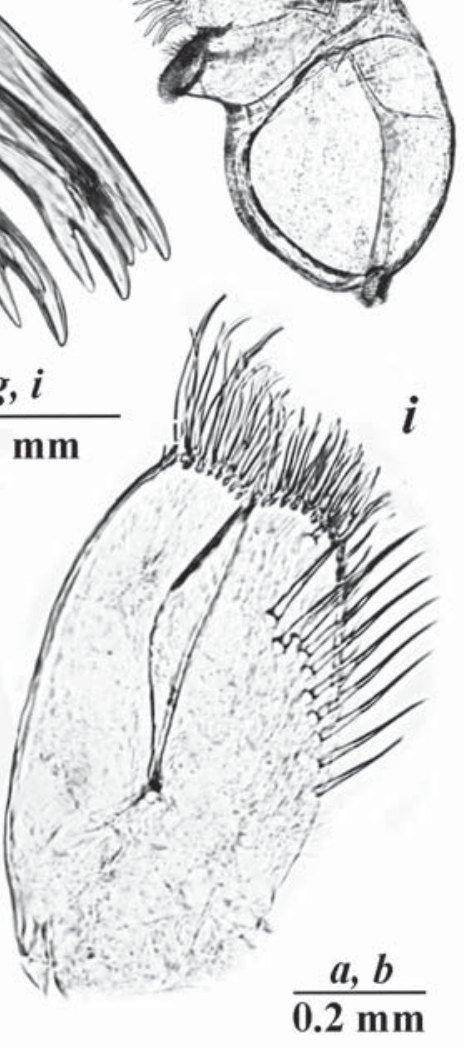

Fig. 4. Volgonyx dershavini (Behning, 1928) comb.n., male: $a$ - lower lip; $b-$ upper lip; $c$ - left mandible; $d-$ same, incisor process and pars incisiva; $e$ - right mandible; $f$ - same, incisor process and pars incisiva; $g$ - maxilla I; $h$ - distal margin of inner plate of maxilla I; $i$ - maxilla II; $j$ - maxilliped.

Рис. 4. Volgonyx dershavini (Behning, 1928) comb.n., самец: $a-$ нижняя губа; $b-$ верхняя губа; $c$ - левая мадибула; $d-$ тоже, режущий отросток и pars incisiva; $e$ - правая мандибула; $f$ - тоже, режущий отросток и pars incisiva; $g$ - максилла I; $h$ дистальный край наружной пластины максиллы I; $i$ - максилла II; $j$ - максиллипед. 
setae; merus with 10-11 distal setae; carpus is 0.55 of length of basis and 0.84 of length of propodus, slightly shorter than propodus, with 5 large separate simple setae and a group of serrated setae in anterior margin and 2 groups of serrated setae in posterior margin; propodus $1.2-1.3 \mathrm{X}$ longer than broad, with 3 groups (with 2-3 setae each) in anterior margin and 4 groups setae in posterior margin; distal margin of palm almost straight, slightly oblique, with double row of 6 inner and 5 outer bifurcate robust setae; palm groove (depression), where dactylus enters, with 4 inner robust setae, 1 large and 3 smaller robust outer setae; dactylus with 1 outer and 2-3 inner setae.

Gnathopod II. Male (Figs $3 g, 8 f, g$ ): coxal plate almost rounded, with 4-6 apical and numerous facial setae, width/ depth ratios are 1.07-1.10; basis width/length is $0.37 / 1$, with numerous (10-11) long setae inserted along posterior margin and 7-9 long simple setae inserted along anterior margin; ischium with 5 long simple setae; merus with 10 distal setae; carpus is 0.45 of length of basis and 0.50 of length of propodus, with 3 anterior and 6 groups of plumose posterior setae; propodus $1.6 \mathrm{X}$ longer than broad, with 2 groups of simple anterior setae, 3 groups (2-4 setae each) of superior medial, 3 groups ( 2 setae each) of inferior medial and 5 groups of posterior setae; palm oblique with a doublerow of 9 inner and 10 outer bifurcate robust setae; palm groove (depression), where dactylus enters, with 5 inner robust and 2 outer robust setae (Figs $3 h, 8 g$ ); dactylus with 3 outer and 9 inner setae.

Female (Fig. $7 c$ ): coxal plate ovale, weakly narrowing distally, with 6 apical and numerous facial setae, width/ depth ratios are 1.3 ; basis width/length is $0.35 / 1$, with numerous (6-7) long setae inserted along posterior margin and 5 long simple setae inserted along anterior margin; ischium with 5 long simple setae; merus with 4 distal setae; carpus is 0.42 of length of basis and 0.52 of length of propodus, with 1 anterior and 4 groups of plumose posterior setae; propodus $1.5 \mathrm{X}$ longer than broad, with 1 group of simple anterior setae, 3 groups (2-4 setae each) of superior medial, 3 groups of posterior setae and 3 inferior medial setae; palm oblique with a double-row of 6 inner and 7 outer bifurcate robust setae; palm groove (depression), where dactylus enters, with 3 inner robust and 2 outer robust setae; dactylus with 2 outer and 4 inner setae.

Pereopod III. Male: (Fig. 5a): coxal plate rounded, weakly narrowing distally, with 7-8 apical and numerous facial setae, width/depth ratios are 1.0; basis is 4.1 times as long as wide, with long anterior and posterior simple setae; merus is 0.65 of length of basis, 1.37 of length of carpus and 1.40 of length of propodus; propodus almost subequal to carpus in length; dactylus is about 0.47 of length of propodus, with plumose seta on outer margin and stout seta on distal corner of inner margin. Female: (Fig. $7 d$ ): coxal plate ovale, weakly narrowing distally, with 6 apical and numerous facial setae, width/depth ratios are 1.3; basis is 3.9-4.0 times as long as wide, with long anterior and posterior simple setae; merus is 0.65 of length of basis, 1.38 of length of carpus and 1.2 of length of propodus; dactylus is about 0.5 of length of propodus, with plumose seta on outer margin and stout seta on distal corner of inner margin.

Pereopod IV: subequal to pereopod III in length. Male: (Fig. $5 b$ ): coxal plate rounded, excavate behind, with 12-13 apical and numerous facial setae, width/depth ratios are 1.0; basis is 4.5 times as long as wide, with long anterior and posterior simple setae; merus is 0.65 of length of basis, 1.33 of length of carpus and 1.39 of length of propodus; dactylus is about 0.46 of length of propodus, setation similar to pereopod III. Female (Fig. 7e): coxal plate rounded, excavate behind, with 9 apical and numerous facial setae, width/ depth ratios are 1.17; basis is 4.4 times as long as wide, with long anterior and posterior simple setae; merus is 0.60 of length of basis, 1.35 of length of carpus and 1.20 of length of propodus; dactylus is about 0.43 of length of propodus, setation similar to pereopod III.

Pereopods V-VII (Figs $5 c-e, 7 f-h$ ): the length of pereopods $\mathrm{V} / \mathrm{VI} / \mathrm{VII}$ is $1 / 1.30 / 1.09$ in males, and $1 / 1.29 / 1.30$ in females.

Pereopod V. Male (Fig. 5c): coxal plate large, bilobate with distinct anterior and posterior lobes; anterior lobe with 3 margin setae, posterior lobe with 7 margin simple setae accompanying a stout seta, each with numerous facial setae; basis is 1.48 times as long as wide, with numerous facial setae, posterior margin convex, armed with 9 shallow serrations, with convex distal corner, anterior margin with 6 split-tipped robust and 4 distal setae; merus is 0.75 of length of basis, 1.03 of length of carpus and 1.05 of length of propodus; dactylus is approximately 0.44 of the length of propodus, setation similar to that of other pereopods. Female (Fig. 7 h): coxal plate large, bilobate with distinct anterior and posterior lobes; anterior lobe with 2 margin setae, posterior lobe with 4 margin simple setae accompanying a stout seta, each with numerous facial setae; basis is 1.37 times as long as wide, with numerous facial setae, posterior margin distinctly convex, armed with 7 shallow serrations, with convex distal corner, anterior margin with 5 split-tipped robust and 4 distal setae; merus is 0.72 of length of basis, 1.05 of length of carpus and 0.91 of length of propodus; dactylus is approximately 0.40 of the length of propodus, setation similar to that of other pereopods.

Pereopod VI. Male (Fig. 5d): coxal plate bilobate, with distinct anterior, posterior lobe; anterior lobe with 2 margin setae, posterior lobe with 4 margin simple setae accompanying a stout seta, each with numerous facial setae; basis is 1.70 times as long as wide, with numerous facial setae, posterior margin weakly concave, armed with 12 shallow serrations, with convex distal corner, anterior margin with 7 split-tipped robust and 4 distal setae; merus is 0.77 of length of basis, 0.97 of length of carpus and 1.02 of length of propodus; dactylus is approximately 0.40 of the length of propodus, setation similar to that of other pereopods. Female (Fig. $7 g$ ): coxal plate bilobate, with distinct anterior, posterior lobe; anterior lobe without margin setae, posterior lobe with 1-2 margin simple setae accompanying a stout seta, each with numerous facial setae; basis is 1.57 times as long as wide, with numerous facial setae, posterior margin weakly convex, armed with 9 shallow serrations, with convex distal corner, anterior margin with 7 split-tipped robust and 3 distal setae; merus is 0.77 of length of basis, 1.04 of length of carpus and 0.91 of length of propodus; dactylus is approximately 0.40 of the length of propodus, setation similar to that of other pereopods.

Pereopod VII. Male (Fig. 5e): coxal plate small, with 13 posterior setae; basis is 1.68 times as long as wide, with numerous facial setae, posterior margin convex, armed with 11 serrations, with weakly convex distal corner, anterior margin with 8 split-tipped robust and 3 distal setae; merus is 0.67 of length of basis, 0.94 of length of carpus and 0.97 of length of propodus; dactylus is approximately 0.36 of the length of propodus, setation similar to that of other pereopods. Female (Fig. $7 h$ ): coxal plate small, with $1-3$ posterior setae; basis is 1.56 times as long as wide, with numerous 


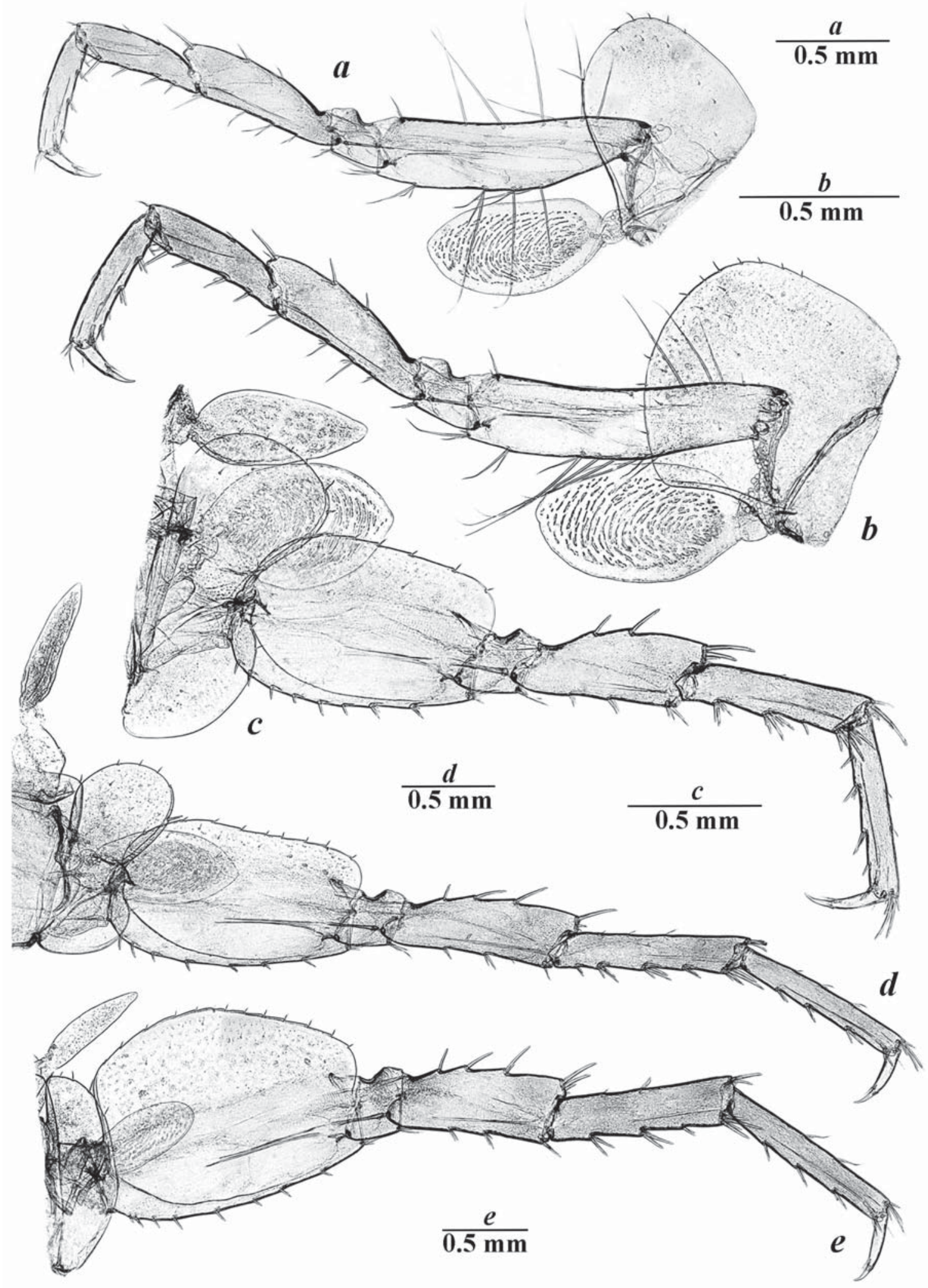

Fig. 5. Volgonyx dershavini (Behning, 1928) comb.n., male: $a$ - pereopod III; $b$ - pereopod IV; $c$ - pereopod V; $d$ - pereopod VI; $e$ - pereopod VII.

Рис. 5. Volgonyx dershavini (Behning, 1928) comb.n., самец: $a$ - переопод III; $b$ - переопод IV; $c$ — переопод V; $d$ - переопод VI; $e$ - переопод VII. 


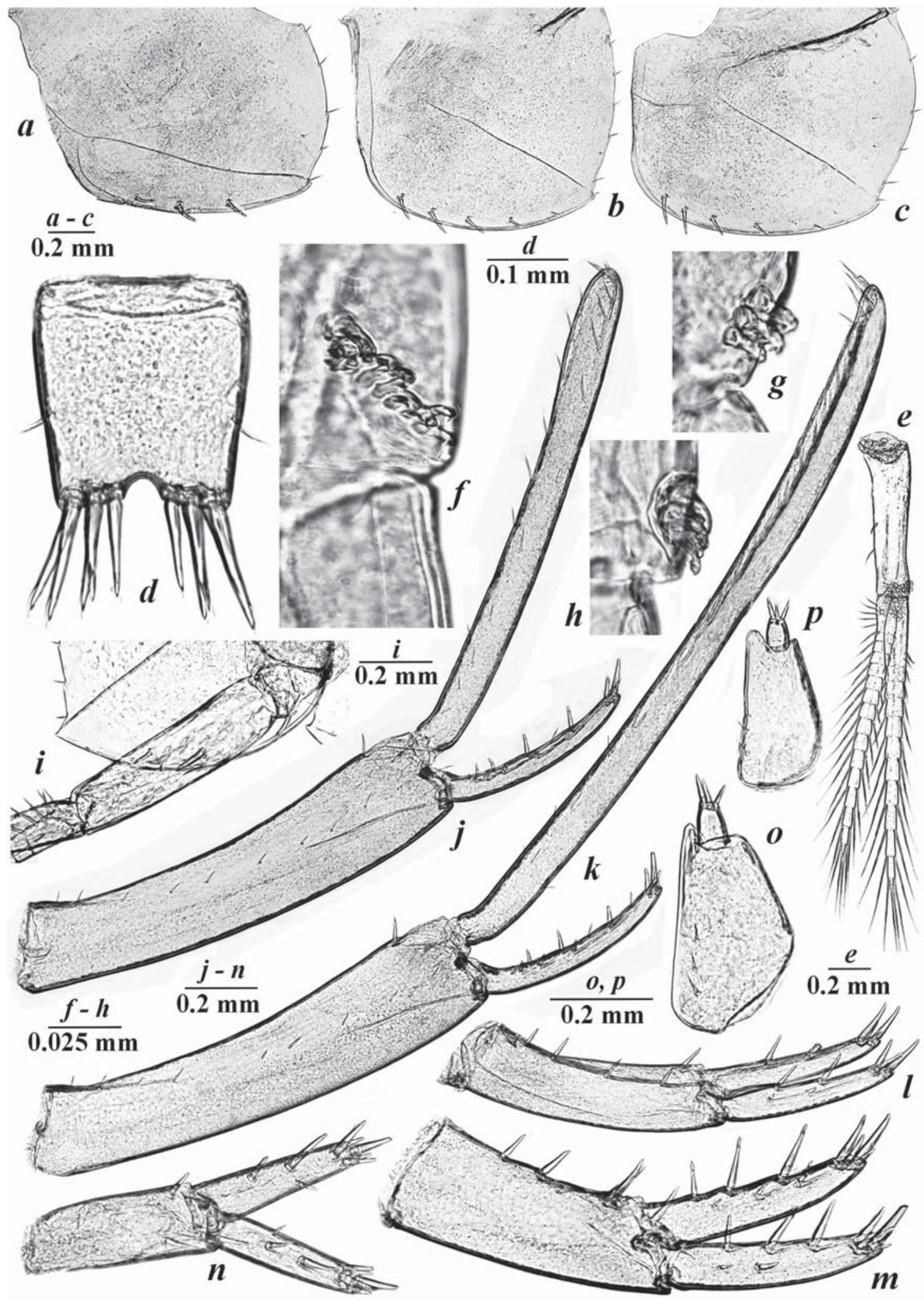

Fig. 6. Volgonyx dershavini (Behning, 1928) comb.n., male $(a-f, i-k, m, o)$, female $(g, h, l, n, p): a-c-$ epimeral plates I-III; $d-$ telson; $e$ - pleopod II; $f-h-$ hooks of retinacula of pleopod III; $i-$ basal segment of pleopod II; $j-l$ - uropod I; $m, n-\operatorname{uropod} \mathrm{II} ; o, p-$ uropod III.

Рис. 6. Volgonyx dershavini (Behning, 1928) comb.n., самец $(a-f, i-k, m, o)$, самка $(g, h, l, n, p): a-c$ - эпимеральные пластины IIII; $d$ - тельсон; $e-$ плеопод II; $f-h$ - сцепляющие крючки ретинакулы плеопода III; $i-$ базальный сегмент плеопод II; $j-l-$ уропод I; $m, n$ - уропод II; $o, p$ - уропод III. 


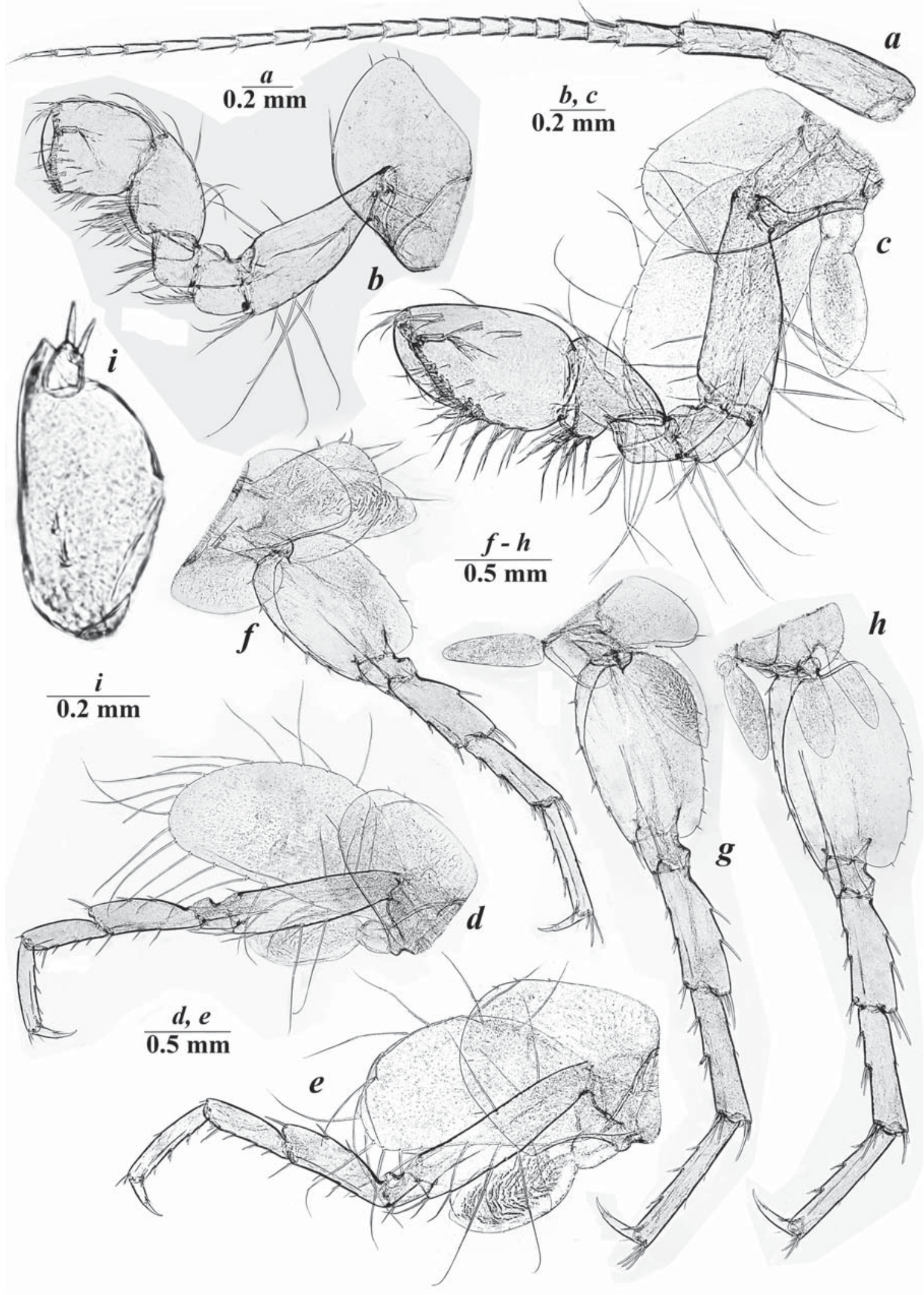

Fig. 7. Volgonyx dershavini (Behning, 1928) comb.n., female: $a$ - antenna I; $b$ - gnathopod I; $c$ - gnathopod II; $d$ - pereopod III; $e$ - pereopod IV; $f$ - pereopod V; $g$ - pereopod VI; $h$ - pereopod VII.

Рис. 7. Volgonyx dershavini (Behning, 1928) comb.n., самка: $a$ - антенна I; $b$ - гнатоподы I; $c$ — гнатоподы II; $d$ - переопод $\mathrm{III} ; e$ - переопод IV; $f$ - переопод V; $g$ - переопод VI; $h$ - переопод VII. 


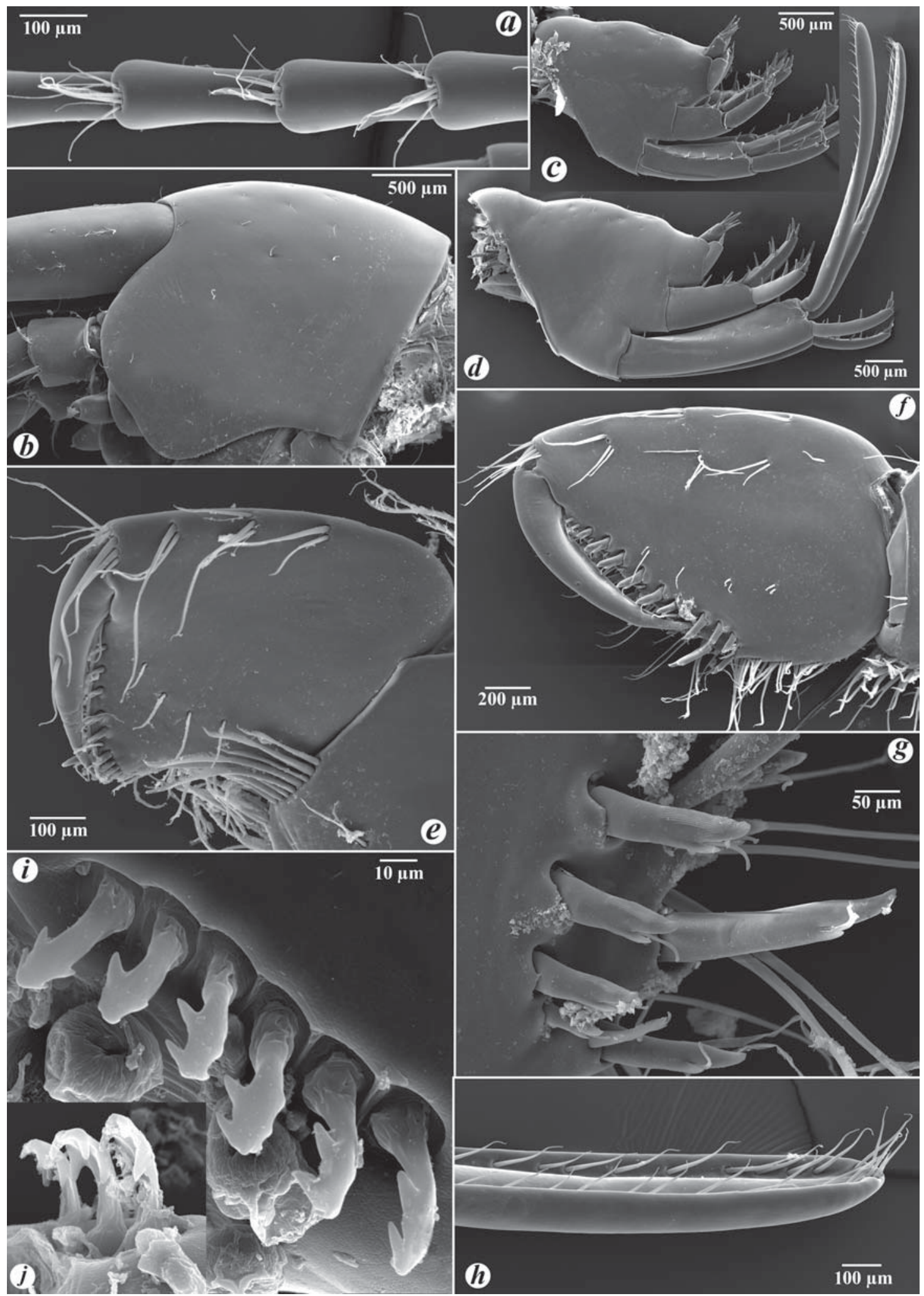

Fig. 8. Volgonyx dershavini (Behning, 1928) comb.n., male $(a, b, d, f-i)$, female $(c, e, j): a$ - segments of antenna I; $b$ - head; $c, d-$ pleon; $e$ - chela of gnathopod I; $f$ - chela of gnathopod II; $g$ - spines of gnathopod II; $h$ - distal part of outer ramus of uropod I; $i, j-$ coupling hooks of retinacula of pleopod III.

Pис. 8. Volgonyx dershavini (Behning, 1928) comb.n., самец $(a, b, d, f-i)$, самка $(c, e, j): a$ - сегменты антенны I; $b$ - голова; $c$, $d$ - плеон; $e$ - клешня гнатопод I; $f$ - клешня гнатопод II; $g$ - шипы гнатопода II; $h$ - дистальная часть наружной ветви уропода $\mathrm{I} ; i, j$ - сцепляющие крючки ретинакулы плеопода III. 
facial setae, posterior margin convex, armed with 9 serrations, with weakly convex distal corner, anterior margin with 7 split-tipped robust and 3 distal setae; merus is 0.62 of length of basis, 0.97 of length of carpus and 0.88 of length of propodus; dactylus is approximately 0.47 of the length of propodus, setation similar to that of other pereopods.

Gills, brood plates (Figs 5, 7): coxal gills on somites IIVII, somite V-VII with lanceolate sternal gill. Male: coxal gills II-VII ovoid, ratio of lengths of gills/bases of pereopod are $0.74 / 1,0.76 / 1,0.72 / 1,0.79 / 1,0.65 / 1$ and $0.43 / 1$, respectively. Female: coxal gills II-VII ovoid, ratio of lengths of gills/ bases of pereopod are $0.72 / 1,0.79 / 1,0.82 / 1,0.88 / 1$, $0.75 / 1$ and $0.45 / 1$, respectively. Slender, setaceous brood plates on somites II-V, decreasing in size posteriorly.

Pleopods (Fig. 6e): pleopod I peduncle in males with 6 8 coupling hooks in retinacula and with large lateral plumose seta; outer and inner rami with 13 and 10 segments, respectively; basal segment of outer ramus with clothes-pin seta; pleopod I peduncle in females with 3-4 coupling hooks in retinacula. Pleopod II peduncle in males with 6-7 coupling hooks in retinacula and with large lateral plumose seta; outer and inner rami with 11 and 15 segments, respectively; basal segment of outer ramus with clothes-pin seta; pleopod I peduncle in females with 3-4 coupling hooks in retinacula. Pleopod III peduncle in males with 7-8 coupling hooks in retinacula (Figs $6 f, 8 i$ ) and with large lateral plumose seta; outer and inner rami with 10 and 13 segments, respectively; basal segment of outer ramus with clothes-pin seta; pleopod I peduncle in females with 3-4 coupling hooks in retinacula (Figs $6 g, h, 8 j$ ).

Epimera: epimeron I (Fig. 6a) distally rounded with small subdistal pointed protrusion, ventral margin with 2-3 spines, posterior margin with 5 setae. Epimeron II (Fig. $6 b$, i) distally rounded with small subdistal pointed protrusion, ventral margin armed with 4-5 spines, posterior margin with 7 setae. Epimeron III (Fig. 6c) distally rounded with small subdistal pointed protrusion, ventral margin armed with 4-5 spines, posterior margin with 6-7 setae.

Urosomites (Fig. 8c,d) completely fused but sutures visible, with sparse setae covering dorsal surface.

Uropod I (Fig. 6j-l): greatly dissimilar in males and females. Male (Figs $6 j, k, 8 c$ ): peduncle about $4.5 \mathrm{X}$ as long as wide; with dorsointernal row of 10 slender spines, one subdistal slender spine and with one dorsoexternal slender spine; outer ramus about $2.5-3 \mathrm{X}$ of the length of inner one endopodite paddle-like (Fig. $8 c, h$ ), with 2 dorsàl row of 20 22 slender spines; exopodite with 4 groups of spines dorsally and medially; 3 apical spines. Female (Fig. $6 l$ ): peduncle about $3.7 \mathrm{X}$ as long as wide; with dorsointernal row of 4 robust spines, one subdistal spine and one dorsoexternal robust spine; outer ramus subequal inner ramus in length; endopodite not paddle-like, with 2 dorsolateral spines; 5 apical spines; exopodite with 2 dorsolateral and 2 mesial spines; 4 apical spines.

Uropod II (Fig. $6 m, n$ ): peduncle subequal in length to inner and outer ramus, with 5 outer robust and no inner robust spines; outer ramus is equal to inner ramus, with 3 outer robust, 2-3 small medial and 5 apical robust spines, without inner robust spines; inner ramus with 3 outer robust, 2-3 small medial and 5 apical robust spines, without inner robust spines. Uropod III (Fig. 6o, p): small, shorter than telson, uniramous; peduncle about $4 \mathrm{X}$ of the length of ramus, with 1-3 medial spines; ramus with 3-4 apical robust spines.

Telson (Fig. $6 d$ ) close to quadrate, about 1.1 (in male) 0.90 (in female) longer than broad; distal margin with shal- low U-shaped distal notch, each lobe armed with 4-5 robust spines, with 1 additional submarginal plumose setae.

COLORATION. The body and appendages yellowish transparent; with small pigmented spots on the anterior lobe of head (Fig. 2).

BODY SIZE. The largest collected male has bl. 11.0 $\mathrm{mm}$, female $-8.0 \mathrm{~mm}$.

GENBANK ACCESSION NUMBERS: MW567461MW567465.

DISTRIBUTION AND ECOLOGY. The type species of the genus, Volgonyx dershavini (Behning, 1928) comb.n., is presently known only from the wells and springs along the upper (right) bank of the Volga river in the city of Saratov and its vicinity. The species was found together with different dwelling insect larvae, such as Baetis rhodani (Pictet, 1843) (Ephemeroptera: Baetidae), Nemoura cinerea (Retzius, 1783) (Plecoptera: Nemouridae), Leuctra fusca (Linnaeus, 1758) (Plecoptera: Leuctridae), Plectrocnemia conspersa (Curtis, 1834) (Trichoptera: Polycentropodidae), Pedicia rivosa (Linnaeus, 1758) (Diptera: Pediciidae).

\section{Genus Pontonyx Palatov et Marin gen.n.}

DIAGNOSIS (based on Sidorov \& Kovtun [2015]). Size relatively large, up to $9 \mathrm{~mm}$ in females, and $11 \mathrm{~mm}$ - in males, without marked sexual dimorphism in uropods. Body smooth, not pigmented (troglomorphic), uronites partly fused, with marked suture between segments, without dorsal spines; head without rostrum, lateral lobe rounded anteriorly; black eye (ommatidia) visible, slightly reduced, large yellow spots present on the dorsolateral surface of the head between eyes. Antenna I longer than antenna II; primary segments of flagellum with transparent aesthetascs; accessory flagellum 2segmented. Antenna II without calceoli in males. Upper lip rounded apically, margin not incised. Mandible with welldeveloped incisor process and lacinia mobilis and underlying row of spines; molar process triturative; palp 3-segmented. Maxilla I: inner plate with 6 long plumose setae apically; outer plate with 7 robust serrate spines apically; palp 2segmented, with short setae and spines apically. Maxilla II: inner plate oval, broader than outer plate, with oblique row of long plumose setae along inner margin; both plates with numerous setae apically. Maxilliped: inner plate with numerous spines and stiff-like setae apically; outer plate with short stiff-like setae on apex and along inner margin; palp 4segmented. Lower lip with well-developed outer lobes; inner lobes small; lateral processes rather short, usually narrowly rounded distally. Gnathopods I-II robust, unequal in size and dissimilar shape (GnI smaller GnII); palm of GnI mostly trapezoidal in shape, while palm of GnII close to tear-like form; palmar margin in both gnathopods with a double row of typically distally notched spine teeth. Pereopods III-IV mostly subequal, pereopod V shorter than pereiopods VI and VII. Coxal gills on pereopods II-VII moderately small, pedicellate, oblong. Posterior corners of pleonal plates sharp, posterior margins with several long setae, ventral margins with numerous spines, differing in size. Pleopods biramous, subequal in length, with 6 coupling hooks in retinacula in both sexes. Uropods I-III biramous, rami and peduncles armed with strong simple spines; uropod I greatly with equal rami, similar in both sexes; uropod II with equal rami, about as long as the length of peduncle; uropod III uniramous, with short 2-segmented ramus, endopodite with characteristic terminal "squamous knob". Telson rectangular in shape, distal margin with deep U-shaped distal notch, reaching almost $1 / 3$ of the length of telson. 
INCLUDED SPECIES. Pontonyx odessana (Sidorov et Kovtun, 2015) comb.n. (the type species of the genus) and Pontonyx osellai (Ruffo, 1972) comb.n.

ETYMOLOGY. The genus is named after its distribution along the coastline of the Black Sea (Greek Ev́ $\xi \varepsilon v v o s$

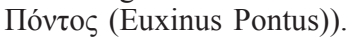

DIFFERENTIAL DIAGNOSIS. According to phylogenetic reconstruction based on molecular genetic analysis (COI mtDNA), Pontonyx gen.n. belongs to the Stygobromus-clade (-Fig. 1), being sister taxa to all other genera in the group (Fig. 1) or inside the group as sister taxa to Volgonyx gen.n. (Fig. 1C). At the same time, there is no doubt that the genus occupies a well-isolated distant position from all other selected Eurasian crangonyctid genera (Fig. 1).

Based on morphology the new genus can be distinctly separated from the Western Eurasian genus Synurella s.str. (with the type species Synurella ambulans (F. Müller, 1846) [Sidorov, Palatov, 2012], also including S. donensis from "dershavini"-group (see above)) by the following features: 1) males are distinctly larger than females (vs. females are distinctly larger than males in S. ambulans); 2) not pigmented and rather elongated (troglomorphic) body (vs. pigmented stout body in $S$. ambulans); 3 ) the absence of calceoli on antenna II (vs. present in $S$. ambulans); 4) pleopods with 5 6 coupling hooks in retinacules (vs. only 2 hooks in retinacules in S. ambulans); and 5) the presence of characteristic terminal "squamous knob" on endopodite of uropod III (vs. absent in S. ambulans).

From Volgonyx dershavini (Behning, 1928) comb.n., referring to the Synurella s.1. "dershavini"-group together with Pontonyx gen.n. by Sidorov \& Kovtun [2015], the new genus can be clearly separated by: 1) presence of blackpigmented eyes (ommatidia); 2) sharply produced posteroventrally epimeral plates I-III; 3) similar rami, equal to peduncle of uropod I in both sexes; and 4) telson with wellmarked deep distal notch.

From the Southern Siberian Palearcticarellus (with the type species Palearcticarellus smirnovi Palatov et Marin, 2020) [Sidorov et al., 2010; Palatov, Marin, 2020], the new genus can be separated by 1) presence of males, and distinct sexual dimorphism in size (only females are known in Palearcticarellus); 2) partly fused urosomal segments (vs. free segments in in Palearcticarellus); 3) presence of black-pigmented eyes (ommatidia) (vs. absent in Palearcticarellus); 4) well developed distal segment of accessory flagellum of antenna I (vs. mostly reduced in Palearcticarellus); 5) gnathopods I-II different in size/shape, especially smaller GnI (vs. almost equal gnathopods I-II in Palearcticarellus); and 6) telson with deep U-shaped notch (vs. feebly developed distal notch in in Palearcticarellus).

From the Caucasian genus Lyurella (with the type species Lyurella hyrcana Derzhavin, 1939 [Derzhavin, 1939; Sidorov, 2015], the new genus can be separated by: 1) nonpigmented elongated body (vs. pigmented orange body and large well-developed black ommatidia in Lyurella); 2) gnathopods I-II different in size/shape, especially smaller GnI and tear-like shape of GnII (vs. almost equal gnathopods III in Lyurella, with rectangular shape of GnII);3) absence of additional spines on dactyli of pereopods III-VII (vs. present in Lyurella); 4) 2-segmented outer rami of uropod III with characteristic terminal "squamous knob" on endopodite (1segmented rami and endopodite without "squamous knob" in Lyurella); 5) 5-6 coupling hooks in retinacules of pleopods (vs. 3-4 hooks in Lyurella); and 6) telson with deep U- shaped notch (vs. feebly developed distal notch in Lyurella).

From the Eastern Eurasian Eosynurella [Martynov, 1931] and Lesser Caucasian Diasynurella [Behning, 1940] it can be separated by 1) non-pigmented elongated body with reduced eyes (ommatidia) (vs. pigmented orange body and large well-developed black eyes in Eosynurella, but completely reduced in Diasynurella); 2) longer antenna I-II and different shape of coxal gills [Martynov, 1931]; 3) presence of characteristic terminal "squamous knob" on endopodite of uropod III; 4) presence of 5-6 coupling hooks in retinacules of pleopods (vs. usually only 2 hooks in retinacules of pleopods in Eosynurella and Diasynurella); and 5) telson with deep U-shaped notch (vs. feebly developed distal notch in Eosynurella and deep V-shaped notch in Diasynurella).

From the Far-Eastern Amurocrangonyx [Sidorov, Holsinger, 2007], and all North American crangonyctid genera, such as Stygobromus, Crangonyx, Stygonyx and Bacturus, the new genus can be clearly separated by 1) presence of coxal gills 7; 2) 5-6 hooks in retinacules of pleopods; 3 ) uropod III uniramous, with small distal article, about $1 / 4$ of the length of peduncle, and with characteristic terminal "squamous knob" on endopodite. These genera are very distant according to molecular genetic studies (see Fig. 1).

DISTRIBUTION AND ECOLOGY. The type species of the genus is known only from the type locality — various flooded parts of the catacombs under the Slobodka District

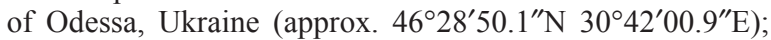
reaching the density about 50 individuals $/ \mathrm{m}^{2}$ in areas where karst sinkholes with the water containing large amount of organics (earth, rotten wood, etc.) [Sidorov, Kovtun, 2015]. Water parameters at the collecting site: temperature $12.5^{\circ} \mathrm{C}$, salinity 3.74\% [Kovtun, Sidorov, 2014]. Unidentified stygobiotic Copepoda (Crustacea) also known from the same locality [Sidorov, Kovtun, 2015].

\section{Discussion}

Well-isolated distant phylogenetic positions of Volgonyx gen.n. and Pontonyx gen.n. within the Stygobromus-clade and from both Holarctic, Iceland and Palearctic crangonyctid genera shows their relic origin. The calculated $p$-distances and estimated node age, based suggestions of COI substitution rates by Guy-Haim et al. [2018] as 0.0077 substitution/Mya for Typhlocaris spp., shows that new genera separated from Holarctic relatives of the genus Stygobromus for 40,07/33,38 Mya, respectively, and from Iceland Crangonyx islandicus for 40.53/37.48 Mya, respectively (see Table 2 ). At the same time, such divergence is obviously correlated in time with the breakup of Laurasia and separation of Iceland from Europe and North America occurred in the late Mesozoic (Cretaceous) (135-60 Mya) [Copilaş-Ciocianu et al., 2019]. According to these data, the proportion of $p$-distances/divergence time (COI substitution rates) can be calibrated as $0.0022-0.0042 / 0.0019-0.0051$ substitution/Mya for COI mtDNA gene marker, respectively.

Currently, Volgonyx dershavini (Behning, 1928) comb.n. is the only endemic genus for the Volga Upland. In addition, as far as we know, it is the only endemic animal species known for the middle-Volga region, and the northernmost locally widespread en- 
demic of Eastern Europe among freshwater crustaceans. At the same time, it should be noted that the fauna of groundwaters and spring resources of the Volga Upland is extremely poorly studied. Thus, it is quite possible to detect new endemic forms in the groundwater of the Volga upland, especially given the noticeable level of endemism of the local flora, which has been studied in much more detail [Vasyukov et al., 2015].

On the other hand, our present research has revealed that Volgonyx dershavini (Behning, 1928) comb.n. is more widely distributed than previously known, similar to the distribution of the species of the genus Palearcticarellus [Palatov, Marin, 2020]. Actually, Behning [1928] wrote that the species is quite common in the springs and wells of the city of Saratov, and the present study describes it distribution along the upper (right) bank of Volga river for $50 \mathrm{~km}$ far from the city in both directions. Moreover, Volgonyx dershavini (Behning, 1928) comb.n., a relatively largesized species which are not characterized with the cryptic lifestyle, unlike, for example with the extremely small-sized Palearcticarellus mikhaili [Sidorov et al., 2010] from the Kurai steppe of the Altai Republic [Palatov, Marin, 2020], is quite abundant in studied springs and wells of the studied region. Therefore, it looks like strange that the species remained unknown from these water sources. It is also interesting to note that in some water sources specimens of Volgonyx dershavini (Behning, 1928) comb.n. were found in greater abundance under/inside clusters of water moss than under rocks in "clean" parts of springs/wells, similar to P. mikhaili [Palatov, Marin, 2020].

Supplementary Figure is available online.

Supplementary Fig. S1 is Figure 1 in hign resolution.

Acknowledgements. The study is supported by the Russian Foundation for Basic Research (RFBR) (grants No. 1834-20105_mol_a ved and 20-04-00803_A). Authors are sending their special thanks to V. Maryinsky (M.V. Lomonosov Moscow State University, Moscow, Russia) for the help during the sampling and Roman A. Rakitov (Paleontological Institute of Russian Academy of Sciences) for his help with SEM photos. Author are very thankful to Dr. Alexey A. Kotov (A.N. Severtsov Institute of Ecology and Evolution of RAS) for valuable comments to the manuscript.

\section{References}

Arbačiauskas K. 2008. Synurella ambulans (F. Müller, 1846), a new native amphipod species of Lithuanian waters // Acta Zoologica Lithuanica. Vol.18. No.1. P.66-68. https://doi.org/ 10.2478/v10043-008-0006-z

Avise J.C. 1993. Perspective: The evolutionary biology of aging, sexual reproduction, and DNA repair // Evolution. Vol.47. No.5. P.1293-1301. https://doi.org/10.1111/j.1558-5646.1993. tb02155.x

Behning A.L. 1928. [Some Data on the Fauna of the Wells of Saratov] // Raboty Volzhskoi Biologicheskoi Stantsii. Vol.10. No.1. P. 32-54 [in Russian].

Behning A.L. 1940. [On Some Crustaceans from the Environs of Bakuriani, Georgian SSR] // Trudy Biologicheskikh Stantsii Narkomprosa Gruzinskoi SSR. Vol.1. P.11-58 [in Russian].
Bousfield E.L. 1973. Shallow-water gammaridean Amphipoda of New England. Ithaca: Cornell University Press. 312 p.

Copilaş-Ciocianu D., Sidorov D.A., Gontcharov A. 2019. Adrift across tectonic plates: molecular phylogenetics supports the ancient Laurasian origin of old limnic crangonyctid amphipods // Organisms Diversity \& Evolution. Vol.19. P.191-207. https://doi.org/10.1007/s13127-019-00401-7

Decu V., Juberthie C., Iepure S., Gheorghiu V., Nazareanu G. 2019. An overview on the subterranean fauna from Central Asia // Ecologica Montenegrina. Vol.20. P.163-188.

Derzhavin A.N. 1939. [The Freshwater Peracarida of the Talysh] // Trudy Zoologicheskogo Instituta Azerbaidjanskogo filiala AN SSSR. Vol.10. P.43-58 [in Russian].

Folmer O., Black M., Hoeh W., Lutz R., Vrijenhoek R. 1994. DNA primers for amplification of mitochondrial cytochrome $\mathrm{c}$ oxidase subunit I from diverse metazoan invertebrates // Molecular Marine Biology and Biotechnology. Vol.3. P.294-299.

Guindon S., Dufayard J.F., Lefort V., Anisimova M., Hordijk W., Gascuel O. 2010. New Algorithms and Methods to Estimate Maximum-Likelihood Phylogenies: Assessing the Performance of PhyML 3.0 // Systematic Biology. Vol.59. No.3. P.307321. https://doi.org/10.1093/sysbio/syq010

Guy-Haim T., Simon-Blecher N., Frumkin A., Naaman I., Achituv Y. 2018. Multiple transgressions and slow evolution shape the phylogeographic pattern of the blind cave-dwelling shrimp Typhlocaris // PeerJ. Vol.6. e5268. https://doi.org/10.7717/ peerj.5268

Hebert P.D.N., Ratnasingham S., de Waard J. 2003a. Barcoding animal life: cytochrome c oxidase subunit 1 divergences among closely related species // Proceedings of the Royal Society of London. Series B (Supplement). Vol.270. P.S96-S99. https:// doi.org/10.1098/rsbl.2003.0025

Hebert P.D.N., Cywinska A., Ball S.L., de Waard J.R. 2003b. Biological identifications through DNA barcodes // Proceedings of the Royal Society of London. Series B. Vol.270. P.313321. https://doi.org/10.1098/rspb.2002.2218

Holsinger J.R. 1974. Systematics of the subterranean amphipod genus Stygobromus (Gammaridae). Part I: Species of the western United States // Smithsonian Contributions to Zoology. Vol.160. P.1-63. https://doi.org/10.5479/si.00810282.160

Holsinger J.R. 1978. Systematics of the subterranean amphipod genus Stygobromus (Gammaridae). Part II: Species of the eastern United States // Smithsonian Contributions to Zoology. Vol.266. P.1-144.

Holsinger J.R. 1994. Pattern and process in the biogeography of subterranean amphipods // Hydrobiologia. Vol.287. No1. P.131-145. https://doi.org/10.1007/BF00006902

Horton T., Lowry J., De Broyer C., Bellan-Santini D., Coleman C.O., Corbari L., Costello M.J., Daneliya M., Dauvin J.-C., Fišer C., Gasca R., Grabowski M., Guerra-García J.M., Hendrycks E., Hughes L., Jaume D., Jazdzewski K., Kim Y.-H., King R., Krapp-Schickel T., Le Croy S., Lörz A.-N., Mamos T., Senna A.R., Serejo C., Sket B., Souza-Filho J.F., Tandberg A.H., Thomas J.D., Thurston M., Vader W., Väinölä R., Vonk R., White K., Zeidler W. 2020. World Amphipoda Database. Crangonyctidae Bousfield, 1973 [Electronic Resource]. Accessed at: http://www.marinespecies.org/aphia.php? $\mathrm{p}=$ taxdetails\&id=430454. Last update on 2020-03-01.

Kimura M. 1980. A simple method for estimating evolutionary rates of base substitutions through comparative studies of nucleotide sequences // Journal of Molecular Evolution. Vol.16. No.2. P.111-120. https://doi.org/10.1007/BF01731581

Kornobis E., Pálsson S., Sidorov D.A., Holsinger J.R., Kristjánsson B.K. 2011. Molecular taxonomy and phylogenetic affinities of two groundwater amphipods, Crangonyx islandicus and Crymostygius thingvallensis, endemic to Iceland // Molecular Phylogenetics and Evolution. Vol.58. No.3. P.527-539. https:// doi.org/10.1016/j.ympev.2010.12.010

Kozlov A.M., Darriba D., Flouri T., Morel B., Stamatakis A. 2019. RAxML-NG: A fast, scalable, and user-friendly tool for maximum likelihood phylogenetic inference // Bioinformatics. Vol.35. No.21. P.1-3. https://doi.org/10.1093/bioinformatics/ btz305 
Kovtun O.A., Sidorov D.A. 2014. [Finding of a new species of subterranean crustacean amphipod of the genus Synurella (Crustacea: Amphipoda, Crangonyctidae) from water flooded catacombs of Odessa (Ukraine)] // Marine Ecological Journal. Vol.13. No.2. P.70 [in Russian].

Kristjánsson B.K., Svavarsson J. 2004. Crymostygidae, a new family of subterranean freshwater gammaridean amphipods (Crustacea) recorded from subarctic Europe // Journal of Natural History. Vol.38. P.1881-1894. https://doi.org/10.1080/ 00222930310001597295

Lowry J.K., Myers A.A. 2013. A phylogeny and classification of the Senticaudata subord. nov. (Crustacea: Amphipoda) // Zootaxa. Vol.3610. P.1-80. https://doi.org/10.11646/zootaxa. 3610.1 .1

Lowry J.K., Myers A.A. 2017. A phylogeny and classification of the Amphipoda with the establishment of the new order Ingolfiellida (Crustacea: Peracarida) // Zootaxa. Vol.4265. P.1-89. https://doi.org/10. 11646/zootaxa.4265.1.1

Martynov A.V. 1919. [On Malacostraca of the Rostov-on-Don Area] // Protokol Zasedaniya Obshchestva Estestvoispytatelei pri Donskom Universitete. Vol.1 No.3. P.39-53 [in Russian].

Martynov A.V. 1931. [On Freshwater Amphipoda and Isopoda of North Yakutia] // Ezhegodnik Zoologicheskogo Muzeya AN SSSR. Vol.32. No.4. P.523-540 [in Russian]

Ruffo S. 1974. Studi sui Crostacei Anfipodi. 75. Il genere Synurella Wrzesn. in Anatolia, descrizione di una nuova specie e considerazioni su Lyurella hyrcana Dersh. (Crustacea, Amphipoda, Gammaridea) // Memorie del Museo Civico di Storia Naturale, Verona. Vol.20. P.389-404.

Özbek M. 2018. An overview on the distribution of Synurella genus in Turkey (Crustacea: Amphipoda) // Ege Journal of Fisheries and Aquatic Sciences. Vol.35. No.2. P.111-114. https://doi.org/10.12714/egejfas.2018.35.2.01

Palatov D.M., Marin I.N. 2020. A new genus of the family Crangonyctidae (Crustacea, Amphipoda) from the Palaearctic, with descriptions of two new species from the foothills of the Altai mountains // Zoologichesky Zhurnal. Vol.99. No.10. P.1160 1186. https://doi.org/10.31857/S004451342010013X

Sidorov D. 2015. The spring-dwelling amphipod genus Lyurella (Peracarida, Amphipoda): systematics, distribution, and affinity, with description of the second representative from the Black Sea coast region // Crustaceana. Vol.88. P.27-50. https:// doi.org/10.1163/15685403-00003392

Sidorov D.A., Holsinger J.R. 2007. Amurocrangonyx, a new genus of subterranean amphipod (Crangonyctidae) from the Russian Far East, with a redescription of the poorly known Crangonyx arsenjevi and comments on biogeographic relationships // Jour- nal of Crustacean Biology. Vol.27. P.660-669. https://doi.org/ 10.1651/S-2817R.1

Sidorov D.A., Kovtun O.A. 2015. Synurella odessana sp. n. (Crustacea, Amphipoda, Crangonyctidae), first report of a subterranean amphipod from the catacombs of Odessa and its zoogeographic importance // Subterranean Biology. Vol.15. P.11-27. https://doi.org/10.3897/subtbiol.15.8820

Sidorov D., Palatov D. 2012. Taxonomy of the spring dwelling amphipod Synurella ambulans (Crustacea: Crangonyctidae) in West Russia: with notes on its distribution and ecology // European Journal of Taxonomy. Vol.23. P.1-19. http://doi.org/ 10.5852/ejt.2012.23

Sidorov D.A., Gontcharov A.A. 2015. Preliminary analysis of phylogenetic relationships of the Asian-Pacific endemial subterranean amphipod genus Pseudocrangonyx among families and genera of crangonyctoidean amphipods inferred by partial LSU rDNA gene sequences // Zoological Science. Vol.32. P.178182. https://doi.org/10. 2108/zs140129

Sidorov D.A., Pankov N.N., Krašheninnikov A.B. 2010. A Bactrurus-like subterranean amphipod (Crangonyctidae) from the Ural Mountain karst region // 20th International Conference on Subterranean Biology: abstract book. Postojna. P.145.

Sidorov D.A., Holsinger J.R., Takhteev V. 2010. Two new species of the subterranean amphipod genus Stygobromus (Amphipoda: Crangonyctidae) from Siberia, with new data on Stygobromus pusillus (Martynov) and remarks on morphology and biogeographic relationships // Zootaxa. Vol.2478. P.41-58. https://doi.org/10.11646/zootaxa.2478.1.2

Svavarsson J., Kristjánsson B.K. 2006. Crangonyx islandicus sp. nov., a subterranean freshwater amphipod (Crustacea, Amphipoda, Crangonyctidae) from springs in lava fields in Iceland // Zootaxa. Vol.1365. P.1-17. https://doi.org/10.11646/ zootaxa.1365.1.1

Takhteev V.V., Berezina N.A., Sidorov D.A. 2015. Checklist of the Amphipoda (Crustacea) from continental waters of Russia, with data on alien species // Arthropoda Selecta. Vol.24. No.3. P.335-370.

Zhang J., Holsinger J.R. 2003. Systematics of the freshwater amphipod genus Crangonyx (Crangonyctidae) in North America // Virginia Museum of Natural History Memoir. Vol.6. P.1-274. https://doi.org/10.1163/156854008X354894

Vasyukov V.M., Senator S.A., Rakov N.S., Saksonov S.V. 2015. [Plants described from the right bank of the Middle Volga] // Botanicheskii Zhurnal. Vol.100. No.1. P.44-59 [in Russian].

Responsible editor K.G. Mikhailov 